\title{
The Volatility Curse: Revisiting the Paradox of Plenty
}

\author{
FREDERICK VAN DER PLOEG \\ STEVEN POELHEKKE
}

\section{CESIFO WORKING PAPER NO. 2616 \\ CAtegory 6: Fiscal Policy, Macroeconomics and Growth \\ APRIL 2009}

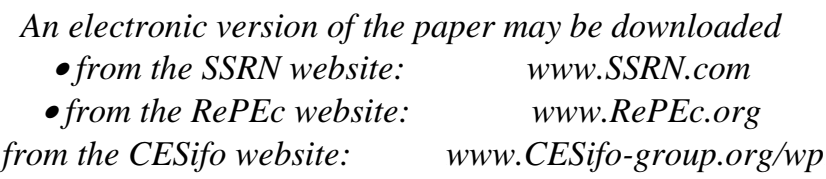




\title{
The Volatility Curse: Revisiting the Paradox of Plenty
}

\begin{abstract}
The volatility of unanticipated output growth in income per capita is detrimental to long-run development, controlling for initial income per capita, population growth, human capital, investment, openness and natural resource dependence. This effect is significant and robust over a wide range of specifications. We unravel the effects of volatility by opening the black box and conditioning the variance of growth shocks on several country characteristics. Natural resource dependence, physical and institutional barriers to trade and associated policy shocks increase volatility sharply and harm growth through this indirect channel. The robust indirect effect of natural resources through volatility trumps any direct effects on economic development, even if natural resource dependence is measured net of extraction costs. Financial development appears to mitigate the harmful causes of volatility. Our panel data estimation confirms our cross-country results, but we also offer evidence that well developed financial systems amplify the effect of short-term terms-of-trade volatility on macroeconomic volatility.
\end{abstract}

JEL Code: C12, C21, C23, F43, G20, O11, O41, Q32.

Keywords: volatility, growth, resource curse, financial development.

\author{
Frederick van der Ploeg \\ Department of Economics \\ University of Oxford \\ Manor Road Building \\ UK - Oxford OX1 3UQ \\ rick.vanderploeg@economics.ox.ac.uk
}

Steven Poelhekke

De Nederlandsche Bank

Postbus 98

1000 AB Amsterdam

The Netherlands

steven.poelhekke@dnb.nl

Revised February 2009 


\section{Introduction}

Institutions, geography and culture are often argued to be the main determinants of economic growth, but economic growth rates are much more variable than these persistent determinants (Easterly et al., 1993). It therefore seems natural to try to understand the deeper causes of macroeconomic volatility. Some highlight the volatility of commodity prices (Deaton, 1999; Blattman, Hwang and Williamson, 2007) and others the volatility of real exchange rates (Hausman et al., 2004; Aghion et al., 2006) or the volatility of inflation and government spending (Fatás and Mihov, 2005). A different approach uses decomposition analysis to identify four reasons why poor countries are relatively volatile: they specialize in volatile sectors, specialize in fewer sectors, suffer from more frequent and severe aggregate shocks and macro fluctuations are more correlated with the shocks of the sector they specialize in (Koren and Tenreyro, 2007). Evidence on the direct effect of volatility on growth is provided by Ramey and Ramey (1995), whom emphasize policy shocks to explain volatility. We follow this latter tack, but probe deeper into the causes of unanticipated growth shocks in income per capita and compare the robustness of our results with a range of alternatives. We first demonstrate that volatility of unanticipated growth is much higher in Africa than in Europe or the US and show that volatility of unanticipated output growth depends on underlying factors like access to waterways, openness to international trade, natural resource dependence, financial development and government spending volatility. We allow for the direct effect of these factors on economic growth and for the indirect effect of these factors through volatility on economic growth. One important observation which this strategy yields is that in contrast to the earlier literature on the natural resource curse (Sachs and Warner, 1995), volatility appears to be an overlooked and important channel of the resource curse. This gives a new interpretation to what is sometimes also called the 'paradox of plenty' (Karl, 1997). To avoid omitted variable bias, we control in all our results for initial income per capita, population growth, investment and human capital.

Our investigations are motivated by some telling stylized facts. A glance at Figure 1 and Table 1 suggests that countries with a high standard deviation of annual growth in GDP per capita typically have lower growth rates. This is especially true for Sub-Saharan Africa and the Middle East \& North Africa and to a lesser extent for Asia and Latin America \& Caribbean, since these economies are much more volatile than Western Europe and North America. Table 1 also indicates that countries with poorly developed financial systems are more volatile. In a companion paper we demonstrate that volatility is the quintessential feature of the resource curse and analyzed which features of resource dependence cause this link to do so much damage to a 
country's growth (van der Ploeg and Poelhekke, 2009). The direct resource curse, which is not a robust effect, is trumped by the indirect effect through volatility.

\section{Figure 1: Volatile Countries Have Lower Annual Growth in GDP per Capita}

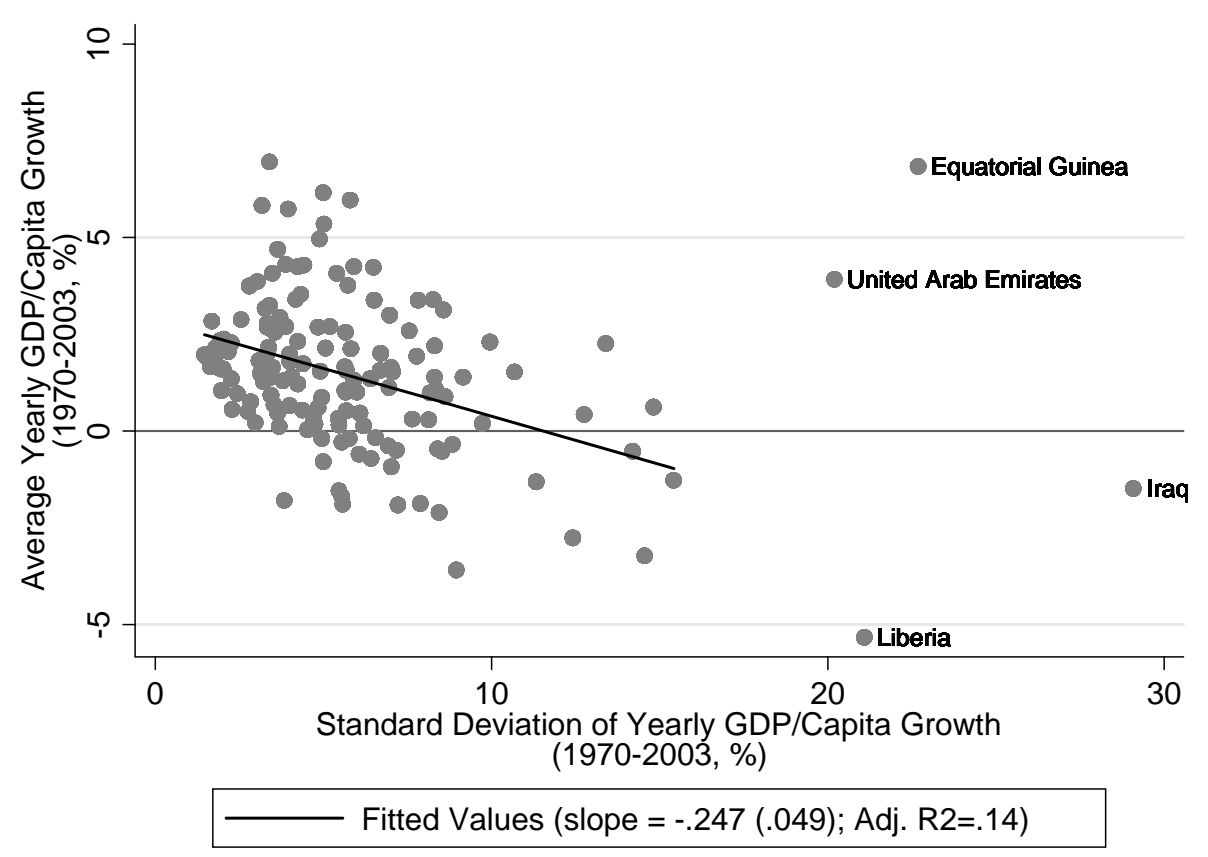

Table 1: Growth, Volatility and Financial Development in the World

Regional Characteristics (\%, 1970-2003, at least 10 observations per country)

\begin{tabular}{|c|c|c|c|c|c|}
\hline \multirow[t]{2}{*}{ Region } & \multicolumn{2}{|c|}{$\begin{array}{l}\text { Yearly real GDP per capita } \\
\text { growth rate }\end{array}$} & \multirow{2}{*}{$\begin{array}{l}\text { Financial } \\
\text { Development } \\
\text { mean }\end{array}$} & \multirow{2}{*}{$\begin{array}{l}\text { Resources } \\
\text { Exports } \\
\text { mean }\end{array}$} & \multirow{2}{*}{$\begin{array}{l}\text { Resource Rents } \\
\text { (Fuels, Ores } \\
\begin{array}{r}\text { \& Metals) } \\
\text { mean }\end{array}\end{array}$} \\
\hline & mean & sd (volatility) & & & \\
\hline Middle East \& North Africa (MENA) & 1.18 & 8.12 & 41.41 & 24.75 & 26.98 \\
\hline Sub-Saharan Africa (SSA) & 0.47 & 6.52 & 17.44 & 19.65 & 5.79 \\
\hline East Asia \& Pacific (EAP) & 2.47 & 5.00 & 51.77 & 16.71 & 4.44 \\
\hline Latin America \& Caribbean (LAC) & 1.47 & 4.54 & 34.87 & 14.59 & 6.31 \\
\hline South Asia (SA) & 2.41 & 4.41 & 17.33 & 4.77 & 1.31 \\
\hline Eastern Europe \& Central Asia (ECA) & 2.56 & 4.34 & 22.70 & 5.57 & 2.23 \\
\hline Western Europe (WE) & 2.35 & 2.33 & 76.08 & 7.86 & 0.55 \\
\hline North America (NA) & 2.09 & 1.90 & 109.36 & 5.88 & 3.41 \\
\hline $\begin{array}{l}1^{\text {st }} \text { quartile Average } \\
\text { Financial Development }(<=16.2) \\
4^{\text {th }} \text { quartile Average Financial }\end{array}$ & 0.70 & 6.40 & 10.38 & 17.06 & 5.14 \\
\hline Development $(>=52.9)$ & 2.32 & 4.40 & 80.92 & 9.89 & 4.99 \\
\hline
\end{tabular}


In this paper our focus is to explain growth volatility in which resource dependence plays a key role. Firstly, we highlight the role played by financial development in the process of economic development. Financial development lowers the volatility of unanticipated output growth and mitigates the adverse effects of shocks to the resource export revenues, government spending and the terms of trade. These interactions are important for the direct effects of a given level of volatility on growth, but they also lower volatility itself. Second, we show that the benefits of financial development are more substantial in the long run. We give a prominent role to the quality of financial markets in understanding how volatility of natural resource export revenues may depress growth. Our results are motivated by the idea that large resource revenues make it easier to overcome negative liquidity shocks, and thus that more volatile resource revenues hamper innovation and growth when financial systems are poorly developed (cf., Aghion et al., 2006). Thirdly, we use instrumental variables to allow for endogeneity of past investments. Fourthly, we offer various robustness checks including some panel estimates. Fifthly, we reexamine the evidence for the volatility channel of the resource curse using rents rather than export revenues and suggest that the level of rents affects economic growth positively while volatility of rents harms growth

Section 2 offers some arguments why volatility may hurt growth performance. Section 3 presents our econometric methodology. Section 4 discusses our cross-country evidence on the sources of macroeconomic volatility and their impact on growth in GDP per capita and on the importance of volatility in understanding the resource. Section 5 performs extensive robustness exercises and offers some panel estimates. Section 6 re-examines the evidence using natural resource rents. Section 7 concludes.

\section{Why Volatility of Natural Resource Revenues Might Hamper Growth?}

Aghion, et al. (2006) shows that macroeconomic volatility driven by nominal exchange rate movements may stunt innovations and thus depress growth in economies with poorly developed financial institutions and nominal wages not reacting immediately to changes in prices. We adopt this argument to show that volatility in natural resource revenues, induced by volatility in primary commodity prices, curbs growth in economies with badly functioning financial systems. Let the law of one price holds, so that the price level $P_{t}$ simply tracks the nominal exchange rate $S_{t}$. In other words, $P_{t}=S_{t} P_{t} *$ where the foreign price level $P_{t} *$ is normalized to unity. Nominal wages are pre-set not knowing the realization of the price level, that is $W_{t}=\phi A_{t} \mathrm{E}\left[P_{t}\right]=\phi A_{t} \mathrm{E}\left[S_{t}\right]$, where $A_{t}$ denotes productivity and $\phi<1$ is a constant. Output follows from the production function $Y_{t}=$ $A_{t} \sqrt{ } l_{t}$, where $l_{t}$ denotes employment. Profits are $\pi_{t} \equiv A_{t} S_{t} \sqrt{ } l_{t}-\phi A_{t} \mathrm{E}\left[S_{t}\right] l_{t}$. The value of 
innovations the next period is $V_{t+1}=V P_{t+1} A_{t+1}$, where next period's productivity is given by $A_{t+1}$ $=\gamma A_{t}$ with $\gamma>1$ if entrepreneurs have sufficient funds to innovate and $A_{t+1}=A_{t}$ otherwise. Firms have sufficient funds (profits plus resource revenues $Q_{t}$ ) to innovate if they have enough cash flow to cope with adverse liquidity shocks, i.e., $\mu\left(\pi_{t}+S_{t} Q_{t}\right)>z P_{t} A_{t}$ where $\mu$ is a measure of financial development and $z$ is a random liquidity shock. If liquidity shocks $z$ are i.i.d. across firms with cumulative density function $\mathrm{F}(z)$, the probability of innovation is given by:

$$
\rho_{t}=\mathrm{F}\left(\frac{\mu\left(\pi_{t}+S_{t} Q_{t}\right)}{S_{t} A_{t}}\right)
$$

Higher profits or natural resource revenues and a more developed financial system imply that more firms are able to overcome liquidity shocks and thus that the probability of innovation is higher. Profit maximization yields the following levels of employment and profits:

$$
l_{t}=\left(\frac{S_{t}}{2 \phi \mathrm{E}\left[S_{t}\right]}\right) \quad \text { and } \quad \pi_{t}=\left(\frac{A_{t} S_{t}^{2}}{4 \phi \mathrm{E}\left[S_{t}\right]}\right)
$$

so that higher productivity, a lower expected price level (i.e., a lower wage) and a higher realized price level boost profits. The probability of innovation is thus given by:

$$
\rho_{t}=\mathrm{F}\left(\mu\left[\left(\frac{S_{t}}{4 \phi \mathrm{E}\left[S_{t}\right]}\right)+\left(\frac{Q_{t}}{A_{t}}\right)\right]\right)
$$

The rate of economic growth increases with the expected probability of innovation:

$$
g_{t} \equiv \frac{\mathrm{E}\left[A_{t+1}\right]-A_{t}}{A_{t}}=(\gamma-1) \mathrm{E}\left[\rho_{t}\right]=(\gamma-1) \mathrm{E}\left[\mathrm{F}\left(\mu\left[\left(\frac{S_{t}}{4 \phi \mathrm{E}\left[S_{t}\right]}\right)+\left(\frac{Q_{t}}{A_{t}}\right)\right]\right)\right] .
$$

Aghion, et al (2006) makes the assumption that the cumulative density function F(.) is concave, so that $\mathrm{E}[\mathrm{F}(c)] \leq \mathrm{F}(\mathrm{E}[c])$. It follows that more exchange rate volatility stunts innovations and curbs growth, especially if the degree of financial development is weak. Moving from a peg to a float thus leads to a lower rate of economic growth. Here we are more interested in the effect of commodity prices on growth performance and the interpretation of equations (3)-(4) is as follows. 
A high and stable level of resource revenues eases liquidity constraints and thus boosts innovations and economic growth. However, for a given expected level of natural resource revenues, more volatility in commodity prices and resource revenues harms innovation and growth, especially if financial development is weak. ${ }^{1}$

Real exchange rate uncertainty induced by swings in commodity prices (Cashin, et al., 2002) exacerbates the negative effects of domestic credit market constraints, so that volatility of commodity prices is indeed expected to curb economic growth. Also, many resource-rich countries suffer from poorly developed financial systems and financial remoteness and thus suffer from bigger macroeconomic volatility (Rose and Spiegel, 2007). Such resource-rich countries with poorly developed financial systems are expected to have poor growth performance.

When only debt contracts are available, bankruptcy is costly and the non-resource traded sector is small, shocks to the demand for non-traded goods and services - associated with shocks to natural resource income - are not accommodated by movements in the allocation of labour but by expenditure switching (Hausman and Ribogon, 2002). This demands much higher relative price movements. Due to bankruptcy costs, interest rates increase with relative price volatility and thus the economy specializes away from non-resource traded goods and services. The less it produces of these goods and services, the more volatile the economy becomes and the higher the interest rate has to be. This causes the sector to shrink until it vanishes. Others stress that resource revenues are used as collateral and encourage countries to borrow 'excessively', which harms the economy both in short and long run (Mansoorian, 1991).

Windfall resource revenues can lead to 'white elephants', import substitution, unsustainable budgetary policies, and favours to political clientele, which cannot be financed once resource revenues dry up. Politicians lose sight of growth-promoting policies and 'value for money’ management. Many developing countries have tried to promote state-led industrialization through prolonged import substitution using tariffs, import quota and subsidies for manufacturing in an attempt to avoid resource dependency. These policies may have been a reaction to the appreciation of the real exchange rate and the decline of the traded manufacturing sectors caused by natural resource dependence. Natural resource wealth may thus prolong bad policies, which eventually have to be reversed. The resulting policy-induced volatility harms growth and welfare.

\footnotetext{
${ }^{1}$ Volatility in itself may also have a positive effect on growth through precautionary saving and thus more investment (Mirman, 1971) or if risky technologies also yield higher expected returns (Black, 1987). These channels are probably more relevant in economies with well developed financial markets. The net effect of volatility on growth will have to be settled empirically.
} 


\section{Estimation Methodology}

Consider a dataset with $N$ countries and a sample period of $T$ years. We specify the following econometric model for growth in GDP per capita (cf., Ramey and Ramey, 1995):

$$
\Delta \log \left(y_{i t}\right)=\lambda \sigma_{i}+\mathbf{X}_{i 70} \boldsymbol{\theta}+d_{t}+\varepsilon_{i t}, \quad \varepsilon_{i t} \square N\left(0, \sigma_{i}^{2}\right), \quad i=1, \ldots, N, \quad t=1, . ., T,
$$

where $y_{i t}$ is GDP per capita in country $i$ for year $t, \sigma_{i}$ is the standard deviation for country $i$ of the residuals $\varepsilon_{i t}, \mathbf{X}_{\mathrm{i} 70}$ a vector of controls for country $i$ and year 1970, and $\boldsymbol{\theta}$ a vector of coefficients assumed constant across countries. The residuals $\varepsilon_{i t}$ are deviations of growth from predicted values based on the controls. The variances of these residuals do not depend on time, but do vary for each country. The standard controls included in $\mathbf{X}_{\mathbf{i} 70}$ are initial log of GDP per capita, average share of investment in GDP, initial human capital proxied by average years of schooling for those older than 25 years in 1970 (Barro and Lee, 1993), and average annual population growth over the sample. Ramey and Ramey (1995) then find statistically significant estimates for $\lambda$ of -0.211 for a sample of 92 countries and -0.385 for the OECD countries. There is thus a negative relationship between volatility and conditional growth performance. In terms of the magnitude of the economic impact, volatility ranks third after the investment share and initial income per capita in the sample of 92 countries and second after initial income per capita for the OECD sample.

We probe deeper and try to explain volatility (the standard deviation of the yearly error in the growth equation), in addition to testing whether natural resource dependence, openness and financial development exert direct effects on growth. We let long-run volatility depend on variables such as resource dependence, initial financial development and openness, and average distance from navigable rivers or coast. We collect these variables in the vector $\mathbf{Z}_{\mathrm{i} 70}$ and estimate the cross-country regressions:

$$
\begin{gathered}
\Delta \log \left(y_{i t}\right)=\lambda \sigma_{i}+\mathbf{X}_{i 70} \boldsymbol{\theta}+\mathbf{Z}_{i 70} \boldsymbol{\beta}+d_{t}+\varepsilon_{i t}, \quad \sigma_{i}^{2}=\exp \left(\mathbf{Z}_{i 70} \gamma+c\right) \quad \text { and } \\
\varepsilon_{i t} \square N\left(0, \sigma_{i}^{2}\right), \quad i=1, . ., N, \quad t=1, . ., T .
\end{gathered}
$$

Average volatility $\sigma_{i}$ is assumed constant over time, but different for each country depending on the initial country characteristics captured in $\mathbf{Z}_{\mathrm{i} 70}$. If countries are similar in terms of the $\mathbf{Z}_{\mathrm{i} 70}$, they are also predicted to have similar volatility. The vector of parameters $\gamma$ measures the average across-country effect of factors like resource dependence, financial development and distance from waterways on volatility. We also allow for direct effects of these variables on growth ( $\boldsymbol{\beta})$.

We estimate parameters $\{\lambda, \theta, \gamma, c$ and $\boldsymbol{\beta}\}$ of (6) by maximizing the likelihood function: 


$$
L=-\frac{N T}{2} \log (2 \pi)-\frac{1}{2} \sum_{t=1}^{T} \log \left(\boldsymbol{\Sigma}_{\mathbf{t}}\right)-\frac{1}{2} \sum_{t=1}^{T} \boldsymbol{\varepsilon}_{\mathrm{t}} \boldsymbol{\Sigma}_{\mathrm{t}}^{-1} \boldsymbol{\varepsilon}_{\mathrm{t}}
$$

where the covariance matrix is defined as $\boldsymbol{\Sigma}_{\mathrm{t}, \mathrm{ij}}=\sigma_{i}^{2}=\exp \left(\mathbf{Z}_{i 70} \gamma+c\right), i=1, . ., N, t=1, . ., T$, and $\boldsymbol{\Sigma}_{\mathrm{t}, \mathrm{j}}=0, i \neq j, t=1, \ldots, N$, and $\left.\boldsymbol{\varepsilon}_{\mathrm{t}} \equiv\left(\varepsilon_{1 t}, . ., \varepsilon_{N t}\right)\right)^{\prime}$ with $\varepsilon_{i t} \equiv \Delta \log \left(y_{i t}\right)-\lambda \sigma_{i}-\mathbf{X}_{i 70} \mathbf{\theta}-\mathbf{Z}_{i 70} \boldsymbol{\beta}-d_{t}, t=1, . ., T$.

The error terms are uncorrelated across countries. ${ }^{2}$

\section{Cross-country Evidence on Volatility and Growth Performance}

The stylized facts suggest that financial development and natural resources play a key role in understanding macroeconomic volatility and growth prospects. Once account is taken of the negative effect of cross-country variations in volatility on the rate of economic growth, resource dependence may exert a positive effect on growth. ${ }^{3}$ From a policy perspective, we must know whether any adverse negative indirect effect of natural resources on growth via volatility of unanticipated output growth dominates any positive direct effect of resource dependence on growth. Furthermore, we want to test whether the adverse effects are weaker with well developed financial institutions. We first investigate, however, the geographical differences in volatility and their effect on growth.

\subsection{The detrimental effects of country-specific and regional volatility}

Table 2 provides cross-country empirical evidence on how much volatility of unanticipated output per capita growth depresses annual growth. Appendix 1 gives the definition of all the variables and their source of origin. The positive coefficients on the average investment share and initial human capital suggest that countries which invest a lot in physical and human capital enjoy a higher growth rate in income per capita, but the coefficient on human capital is not very significant. Similarly, countries with high population growth rates tend to have worse growth performance. And, of course, the significant negative coefficient on initial GDP per capita indicates that poor countries which start off with a low level of income per capita catch up and

\footnotetext{
${ }^{2}$ We could also have explored the effects of autoregressive variances, but our time dimension is not very long and we have no strong prior about what the lags of the variance should be before 1970 .

${ }^{3}$ In fact, if the explanatory variable is natural resource abundance (proxied by natural resource wealth, but only observed in 1996) rather than natural resource dependence, there appears to be a positive effect on growth performance (e.g., Ding and Field, 2005; Alexeev and Conrad, 2005; Brunnschweiler and Bulte, 2008). From our point of view, this does not seem surprising as natural resource wealth is much less volatile than natural resource export revenues and more likely to boost the rate of economic growth.
} 
grow faster ceteris paribus (i.e., conditional convergence). Regression 1 is our benchmark regression, which indicates that volatility of unanticipated output growth negatively affects growth in GDP per capita (cf., Ramey and Ramey, 1995).

Table 2: Natural Resource Curse and Regional Volatility

\begin{tabular}{|c|c|c|c|c|c|c|}
\hline \multirow{2}{*}{$\begin{array}{c}\text { Dependent Variable } \\
\text { (constant } 2000 \text { international dollars, PWT 6.2) }\end{array}$} & \multicolumn{6}{|c|}{ yearly GDP growth per capita 1970-2003 } \\
\hline & 1 & 2 & 3 & 4 & 5 & 6 \\
\hline \multicolumn{7}{|l|}{ Mean equation } \\
\hline Average investment share of GDP 1970-2003 & $\begin{array}{c}0.108 * * * \\
(0.012)\end{array}$ & $\begin{array}{c}0.101^{* * *} \\
(0.014)\end{array}$ & $\begin{array}{c}0.101^{* * *} \\
(0.019)\end{array}$ & $\begin{array}{c}0.070^{* * *} \\
(0.013)\end{array}$ & $\begin{array}{c}0.079 * * * \\
(0.016)\end{array}$ & $\begin{array}{c}0.058^{* * *} \\
(0.018)\end{array}$ \\
\hline Average population growth rate $1970-2003$ & $\begin{array}{c}-0.472 * * * \\
(0.118)\end{array}$ & $\begin{array}{c}-0.484 * * * \\
(0.147)\end{array}$ & $\begin{array}{c}-0.484^{* *} \\
(0.193)\end{array}$ & $\begin{array}{c}-0.346^{* *} \\
(0.145)\end{array}$ & $\begin{array}{c}-0.326^{* *} \\
(0.165)\end{array}$ & $\begin{array}{c}-0.509 * * * \\
(0.151)\end{array}$ \\
\hline log per capita GDP 1970 & $\begin{array}{c}-0.012 * * * \\
(0.001)\end{array}$ & $\begin{array}{c}-0.012 * * * \\
(0.002)\end{array}$ & $\begin{array}{c}-0.012 * * * \\
(0.002)\end{array}$ & $\begin{array}{c}-0.009 * * * \\
(0.002)\end{array}$ & $\begin{array}{l}-0.011^{* * *} \\
(0.002)\end{array}$ & $\begin{array}{c}-0.011 * * * \\
(0.002)\end{array}$ \\
\hline Human capital 1970 & $\begin{array}{l}0.001^{*} \\
(0.000)\end{array}$ & $\begin{array}{l}0.001^{*} \\
(0.001)\end{array}$ & $\begin{array}{c}0.001 \\
(0.001)\end{array}$ & $\begin{array}{l}0.001^{*} \\
(0.000)\end{array}$ & $\begin{array}{l}0.001^{* *} \\
(0.000)\end{array}$ & $\begin{array}{l}0.001^{*} \\
(0.000)\end{array}$ \\
\hline Volatility $\left(\sigma_{i}\right)$ & $\begin{array}{c}-\mathbf{- 0 . 1 1 0 * *} \\
(0.049)\end{array}$ & $\begin{array}{c}\mathbf{- 0 . 2 1 7 * * *} \\
(0.060)\end{array}$ & $\begin{array}{c}\mathbf{- 0 . 2 1 7} * * * \\
(0.069)\end{array}$ & $\begin{array}{c}\mathbf{- 0 . 1 6 6 * * *} \\
(0.048)\end{array}$ & $\begin{array}{c}-\mathbf{- 0 . 1 5 6 * *} \\
(0.067)\end{array}$ & $\begin{array}{c}-\mathbf{0 . 2 4 3 * *} \\
(0.112)\end{array}$ \\
\hline Financial development 1970 & & $\begin{array}{c}0.000 \\
(0.003)\end{array}$ & $\begin{array}{c}0.000 \\
(0.005)\end{array}$ & $\begin{array}{c}0.000 \\
(0.004)\end{array}$ & $\begin{array}{l}-0.002 \\
(0.005)\end{array}$ & $\begin{array}{c}0.003 \\
(0.005)\end{array}$ \\
\hline Sachs Warner updated openness dummy 70 & & $\begin{array}{l}-0.000 \\
(0.003)\end{array}$ & $\begin{array}{l}-0.000 \\
(0.004)\end{array}$ & $\begin{array}{c}0.001 \\
(0.003)\end{array}$ & $\begin{array}{c}0.003 \\
(0.003)\end{array}$ & $\begin{array}{l}-0.004 \\
(0.004)\end{array}$ \\
\hline 1st lag GDP per capita growth & & & & $\begin{array}{c}0.266 * * * \\
(0.031)\end{array}$ & $\begin{array}{c}0.194 * * * \\
(0.031)\end{array}$ & $\begin{array}{c}0.238 * * * \\
(0.028)\end{array}$ \\
\hline Natural resources 1970 & & & & & & $\begin{array}{l}-0.003 \\
(0.021)\end{array}$ \\
\hline Natural resources $1970 *$ openness 1970 & & & & & & $\begin{array}{l}0.050^{*} \\
(0.026)\end{array}$ \\
\hline Natural resources $1970 *$ Fin. Dev. 1970 & & & & & & $\begin{array}{l}-0.038 \\
(0.058)\end{array}$ \\
\hline Constant & $\begin{array}{c}0.110^{* * *} \\
(0.011)\end{array}$ & $\begin{array}{c}0.111^{* * *} \\
(0.015)\end{array}$ & $\begin{array}{c}0.111^{* * *} \\
(0.017)\end{array}$ & $\begin{array}{c}0.085^{* * *} \\
(0.014)\end{array}$ & $\begin{array}{c}0.095^{* * *} \\
(0.015)\end{array}$ & $\begin{array}{c}0.110^{* * *} \\
(0.014)\end{array}$ \\
\hline \multicolumn{7}{|l|}{ Variance equation } \\
\hline Sub-Saharan Africa & & & & & $\begin{array}{c}2.576^{* * *} \\
(0.243)\end{array}$ & $\begin{array}{c}2.568^{* * *} \\
(0.204)\end{array}$ \\
\hline Middle-East \& North Africa & & & & & $\begin{array}{l}3.490 * * * \\
(0.744)\end{array}$ & $\begin{array}{c}1.712 * * * \\
(0.256)\end{array}$ \\
\hline Latin America \& Caribbean & & & & & $\begin{array}{c}1.550 * * * \\
(0.152)\end{array}$ & $\begin{array}{c}1.593^{* * *} \\
(0.174)\end{array}$ \\
\hline Eastern Europe \& Centra Asia & & & & & $\begin{array}{c}1.405^{* * *} \\
(0.033)\end{array}$ & $\begin{array}{c}1.418^{* * *} \\
(0.031)\end{array}$ \\
\hline East Asia \& Pacific & & & & & $\begin{array}{c}0.947 * * * \\
(0.204)\end{array}$ & $\begin{array}{c}1.009^{* * *} \\
(0.192)\end{array}$ \\
\hline South Asia & & & & & $\begin{array}{c}0.576^{* * *} \\
(0.188)\end{array}$ & $\begin{array}{c}0.455^{* *} \\
(0.184)\end{array}$ \\
\hline Western Europe & & & & & $\begin{array}{l}0.273^{*} \\
(0.146)\end{array}$ & $\begin{array}{c}0.204 \\
(0.151)\end{array}$ \\
\hline $\begin{array}{l}\text { North America } \\
\text { (least volatile) }\end{array}$ & & & & & \multicolumn{2}{|c|}{$\begin{array}{c}\text { Reference region } \\
\text { (least volatile) }\end{array}$} \\
\hline Constant & $\begin{array}{c}-3.823^{* * *} \\
(0.118)\end{array}$ & $\begin{array}{l}-5.754 * * * \\
(0.260)\end{array}$ & $\begin{array}{c}-5.754 * * * \\
(0.015)\end{array}$ & $\begin{array}{c}-5.595^{* * *} \\
(0.024)\end{array}$ & $\begin{array}{c}-7.771 * * * \\
(0.023)\end{array}$ & $\begin{array}{c}-7.797 * * * \\
(0.031)\end{array}$ \\
\hline Country dummies in variance eq. & yes & yes & yes & yes & no & no \\
\hline Observations & 3448 & 2646 & 2646 & 2570 & 2570 & 2185 \\
\hline Countries & 103 & 79 & 79 & 79 & 79 & 65 \\
\hline Log likelihood & 5898.5 & 4847.1 & 4847.1 & 4795.7 & 4329.8 & 4017.9 \\
\hline
\end{tabular}

Standard errors in parentheses ${ }^{* * *} \mathrm{p}<0.01,{ }^{* *} \mathrm{p}<0.05,{ }^{*} \mathrm{p}<0.1$. Regressions $3-6$ use clustered standard errors (by country). 
Regression 2 shows that this is robust to controls for openness and the initial level of financial development, which both do not have an effect on growth. One explanation may be that the effects of these variables are picked up by the effect of volatility on growth performance.

We are worried that the errors in our explanation of growth in GDP per capita ('growth shocks') are not independent within countries. We therefore cluster the standard errors by country in regression 3 and all further regressions. The negative volatility effect is still significant. The correlation between growth shocks is made explicit in regression 4 where we include a lagged growth rate in the mean equation, showing the persistence of growth.

In order to get an initial understanding of the sources and origins of volatility, regression 5 explains volatility by regional dummies instead of country dummies. Interestingly, Sub-Saharan Africa and the Middle-East and North Africa are much more volatile and thus suffer much more from bad growth prospects. If Sub-Saharan Africa would have the same volatility as East Asia and the Pacific, its long run annual growth rate would be 0.65 percentage point higher. ${ }^{4}$ In contrast to much of the existing empirical literature, financial development, openness to international trade ${ }^{5}$ and various interaction terms are statistically insignificant explanatory factors of cross-country variations in growth in GDP per capita. One possible explanation of this is that the effects of these variables are picked up by the effect of volatility on growth performance. We return to that in section 3.2. Regression 6 also indicates that, controlling for all traditional factors explaining cross-country differences in growth performance, there is no evidence of a traditional resource curse: natural resource exports as a percentage of GDP are insignificant and there is also no evidence that countries closed to trade or financially underdeveloped suffer from a curse. ${ }^{6}$

Regional dummies use more aggregate information than the country dummies and merely give insight in the geographical distribution of volatility. It is therefore important to try to explain why some countries are more volatile than other countries, which is what we turn to now.

\subsection{Opening the black box: Underlying determinants of volatility and the resource curse}

So far we have shown that volatility is an important drag on growth and that some continents, notably Africa, experience very unstable growth. Boom periods are followed by sharp busts which are destructive enough to harm growth in the long run. To understand what it is that makes some countries so unstable we allow volatility to depend on observable country characteristics in

\footnotetext{
${ }^{4} 0.65 \%=-0.156 * \sqrt{\exp (-7.771)} *\{\sqrt{\exp (0.947)}-\sqrt{\exp (2.576)}\}$

${ }^{5}$ We use the openness variable of Sachs and Warner (1997a) as expanded by Wacziarg and Welch (2008). Instead of 'years open to trade' we use initial (1970) openness to minimize reverse causality concerns. ${ }^{6}$ We use the openness variable of Sachs and Warner (1997) as improved and expanded by Wacziarg and Welch (2008).
} 
Table 3: Underlying Determinants of Volatility and Correcting for Endogeneity

\begin{tabular}{|c|c|c|c|c|c|}
\hline "Dependent Variable & yearly GDP & owth per cap & $1970-2003$ & $\begin{array}{c}\text { Average } \\
\text { investment } \\
\text { share GDP } \\
1970-2003\end{array}$ & $\begin{array}{c}\text { yearly } \\
\text { GDP } \\
\text { growth per } \\
\text { capita } \\
1970-2003\end{array}$ \\
\hline $\begin{array}{c}\text { (constant } 2000 \text { international dollars, PWT } \\
6.2 \text { ) }\end{array}$ & 7 & 8 & $\begin{array}{l}\text { 9a } \\
\text { ML }\end{array}$ & $\begin{array}{l}\text { 9b OLS } \\
1^{\text {st }} \text { Stage }\end{array}$ & $\begin{array}{c}\text { 9c } \\
\text { IV-ML }\end{array}$ \\
\hline \multicolumn{6}{|l|}{ Mean equation } \\
\hline Average investment share of GDP ' 70 -` 03 & $\begin{array}{c}0.069 * * * \\
(0.026)\end{array}$ & $\begin{array}{l}0.054^{* *} \\
(0.025)\end{array}$ & $\begin{array}{l}0.047^{*} \\
(0.025)\end{array}$ & & $\begin{array}{l}0.126^{* *} \\
(0.052)\end{array}$ \\
\hline $1^{\text {st }}$ lag GDP per capita growth & $\begin{array}{c}0.164 * * * \\
(0.043)\end{array}$ & $\begin{array}{l}0.223^{* * *} \\
(0.026)\end{array}$ & $\begin{array}{c}0.224 * * * \\
(0.027)\end{array}$ & $\begin{array}{c}0.053 * * \\
(0.022)\end{array}$ & $\begin{array}{c}0.217 * * * \\
(0.029)\end{array}$ \\
\hline Average population growth rate $1970-2003$ & $\begin{array}{c}-0.470 * * * \\
(0.151)\end{array}$ & $\begin{array}{c}-0.503 * * * \\
(0.117)\end{array}$ & $\begin{array}{c}-0.492 * * * \\
(0.122)\end{array}$ & $\begin{array}{c}0.260 \\
(0.835)\end{array}$ & $\begin{array}{c}-0.467 * * * \\
(0.133)\end{array}$ \\
\hline log per capita GDP 1970 & $\begin{array}{c}-0.013^{* * *} \\
(0.003)\end{array}$ & $\begin{array}{c}-0.013^{* * *} \\
(0.002)\end{array}$ & $\begin{array}{c}-0.013^{* * *} \\
(0.002)\end{array}$ & $\begin{array}{c}-0.026^{* *} \\
(0.012)\end{array}$ & $\begin{array}{c}-0.012^{* * *} \\
(0.002)\end{array}$ \\
\hline Human capital 1970 & $\begin{array}{l}0.002 * * \\
(0.001)\end{array}$ & $\begin{array}{l}0.001^{* *} \\
(0.001)\end{array}$ & $\begin{array}{l}0.002^{* *} \\
(0.001)\end{array}$ & $\begin{array}{c}0.013 * * * \\
(0.003)\end{array}$ & $\begin{array}{c}0.001 \\
(0.001)\end{array}$ \\
\hline Volatility $\left(\sigma_{i}\right)$ & $\begin{array}{c}-\mathbf{0 . 3 0 2} * * * \\
(0.091)\end{array}$ & $\begin{array}{c}-\mathbf{0 . 7 9 0 * * *} \\
(0.291)\end{array}$ & $\begin{array}{c}-\mathbf{0 . 9 3 4 * * *} \\
(0.317)\end{array}$ & & $\begin{array}{c}-\mathbf{0 . 8 4 8 * *} \\
(0.387)\end{array}$ \\
\hline Financial development 1970 & $\begin{array}{c}-0.011^{* *} \\
(0.005)\end{array}$ & $\begin{array}{c}-0.014 * * \\
(0.007)\end{array}$ & $\begin{array}{c}-0.017 * * \\
(0.007)\end{array}$ & $\begin{array}{l}0.067 * \\
(0.038)\end{array}$ & $\begin{array}{c}-0.020^{* * *} \\
(0.006)\end{array}$ \\
\hline Sachs Warner updated openness dummy 70 & $\begin{array}{c}0.000 \\
(0.003)\end{array}$ & $\begin{array}{l}-0.006 \\
(0.004)\end{array}$ & $\begin{array}{l}-0.007 \\
(0.004)\end{array}$ & $\begin{array}{c}0.058 * * * \\
(0.018)\end{array}$ & $\begin{array}{c}-0.011 * * \\
(0.005)\end{array}$ \\
\hline Natural resources 1970 & & $\begin{array}{c}0.020 \\
(0.015)\end{array}$ & & & \\
\hline Point-source resources 1970 & & & $\begin{array}{l}0.045^{*} \\
(0.027)\end{array}$ & $\begin{array}{c}0.242 * * * \\
(0.040)\end{array}$ & $\begin{array}{c}0.027 \\
(0.030)\end{array}$ \\
\hline Constant & $\begin{array}{c}0.128 * * * \\
(0.026)\end{array}$ & $\begin{array}{c}0.148 * * * \\
(0.025)\end{array}$ & $\begin{array}{c}0.163^{* * * *} \\
(0.028)\end{array}$ & $\begin{array}{c}0.314 * * * \\
(0.090)\end{array}$ & $\begin{array}{c}0.142^{* * *} \\
(0.034)\end{array}$ \\
\hline Landlocked dummy & & & & $\begin{array}{l}-0.012 \\
(0.013)\end{array}$ & \\
\hline \% Population in Temperate Climate Zone & & & & $\begin{array}{c}0.003 \\
(0.026)\end{array}$ & \\
\hline Ethnic Fractionalization Index & & & & $\begin{array}{c}-0.072 * * * \\
(0.026)\end{array}$ & \\
\hline \multicolumn{6}{|l|}{ Variance equation } \\
\hline Financial development 1970 & $\begin{array}{c}-1.695 * * * \\
(0.055)\end{array}$ & $\begin{array}{c}-1.200 * * * \\
(0.096)\end{array}$ & $\begin{array}{c}-1.271 * * * \\
(0.069)\end{array}$ & & $\begin{array}{c}-1.284 * * * \\
(0.097)\end{array}$ \\
\hline Sachs Warner updated openness dummy 70 & $\begin{array}{c}-0.883 * * \\
(0.350)\end{array}$ & $\begin{array}{c}-0.725^{* * *} \\
(0.207)\end{array}$ & $\begin{array}{c}-0.741 * * * \\
(0.167)\end{array}$ & & $\begin{array}{c}-0.729 * * * \\
(0.087)\end{array}$ \\
\hline Distance to nearest navigable river or coast & $\begin{array}{c}0.001 * * * \\
(0.000)\end{array}$ & $\begin{array}{c}0.001^{* * *} * \\
(0.000)\end{array}$ & $\begin{array}{c}0.001 * * * \\
(0.000)\end{array}$ & & $\begin{array}{c}0.001 * * * \\
(0.000)\end{array}$ \\
\hline Natural resources 1970 & & $\begin{array}{c}1.185 * * * \\
(0.282)\end{array}$ & & & \\
\hline Point-source resources 1970 & & & $\begin{array}{l}1.385^{* *} \\
(0.623)\end{array}$ & & $\begin{array}{c}1.421^{* *} \\
(0.584)\end{array}$ \\
\hline Diffuse resources 1970 & & & $\begin{array}{c}0.426 \\
(0.350)\end{array}$ & & $\begin{array}{c}0.590 \\
(0.430)\end{array}$ \\
\hline Constant & $\begin{array}{c}-5.743 * * * \\
(0.268)\end{array}$ & $\begin{array}{c}-6.129 * * * \\
(0.057)\end{array}$ & $\begin{array}{c}-6.045^{* * *} \\
(0.059)\end{array}$ & & $\begin{array}{c}-6.062 * * * \\
(0.025)\end{array}$ \\
\hline $\begin{array}{c}\text { F-stat. on excl. instruments } \\
\text { (if only ethnic fractionalization used) } \\
\text { Hansen overidentification J-statistic } \\
\text { (p-value) }\end{array}$ & & & & $\begin{array}{c}4.47 \\
(11.79) \\
0.143\end{array}$ & \\
\hline $\mathrm{R} 2$ & & & & 0.72 & \\
\hline Country dummies in variance eq. & no & no & no & no & No \\
\hline Observations & 2471 & 2024 & 2024 & 2024 & 2024 \\
\hline Countries & 76 & 62 & 62 & 62 & 62 \\
\hline Log likelihood & 3968.3 & 3620.0 & 3622.3 & 3812.1 & 3622.7 \\
\hline
\end{tabular}

Clustered (by country) standard errors in parentheses ${ }^{* * *} \mathrm{p}<0.01,{ }^{* *} \mathrm{p}<0.05,{ }^{*} \mathrm{p}<0.1$. 
regression 7, such as openness to trade, financial development, and geographic isolation as captured by the average distance to navigable rivers or the coast. Countries where firms and households have better access to credit and the financial sector is more developed, can count on much lower volatility and thus improved growth prospects (Aghion et al., 2006; Rose and Spiegel, 2007). ${ }^{7}$ The same holds for openness to international trade. It appears that their effects on growth work primarily through the volatility channel. Physical barriers to trade indeed increase volatility, since they limit diversification of sectors (Malik and Temple, 2006). Regression 8 tests whether there is any evidence for a natural resource curse along the lines of Sachs and Warner (1995). Interestingly, we do not find any significant direct effect of resource dependence on growth once volatility is taken account of. On the other hand, resource dependence has a sizeable and significant positive effect on volatility, confirming our suspicion that volatile world commodity prices are a major cause of macroeconomic volatility and poor growth performance in resource dependent countries. ${ }^{8}$ The volatility coefficient $\lambda$ has increased in magnitude. This is because we force countries with similar initial characteristics to have similar volatility, something which the parsimonious country dummies did not.

\subsection{Instrumenting to deal with endogenous nature of investment shares}

Investment leads to growth, but we have to address the fact that growing countries may also attract more investment, so the direction of causality may go either way. Even though we control for openness and financial development, we probably do not capture enough of the institutional effects on growth and investment. In addition, our measure of natural resource dependence may be too broad, which is why we split it into point-source ${ }^{9}$ and diffuse resources ${ }^{10}$. We therefore look for an exogenous variable that strongly predicts the investment share, but does not affect growth or correlate with other important unobserved characteristics. We choose to instrument the investment share with an index of ethno-linguistic fractionalization. This index measures the probability that two randomly selected individuals from a given country will not belong to the

\footnotetext{
${ }^{7}$ The direct effect of financial development on growth is actually negative. Since the effect of financial development on volatility is already controlled for, this could reflect that highly financially developed countries were also rich countries in 1970. The negative coefficient could therefore reflect the conditional convergence effect of initial GDP per capita.

${ }^{8}$ This result complements other transmission channels of the resource curse, see Gylfason (2001).

${ }^{9}$ These include oil, gas, ores and minerals, which are typically produced in concentrated locations.

${ }^{10}$ Diffuse natural resources include agricultural raw materials and foods such as livestock, coffee, bananas or tobacco, which are typically produced throughout the country.
} 
same ethnic group (Montalvo and Reynal-Querol, 2005a). ${ }^{11}$ The rationale is that trust, ability to communicate and social cohesion are essential prerequisites for successful investment. Fractionalized countries have lower levels of trust, more corruption, less transfers, subsidies and political rights (Alesina et al, 2003). These factors should lower the investment rate, since they increase uncertainty about returns and expropriation. ${ }^{12}$ We also assume that ethno-linguistic fractionalization is randomly 'assigned' to countries and mostly historically determined. Countries should also not have systematically different growth rates depending on their degree of ethnic fractionalization. We suspect that this is the case given the very different growth experiences of countries among the top-ten of ethnic fractionalization, i.e., Canada, Senegal, India and Mali. In the bottom-ten of least fractionalized countries are Norway, Japan, Tunisia, and Greece. We also include two geographical variables: whether a country is landlocked or not, and a climate variable. Investment opportunities may be lower if it is more difficult for a country to diversify and export. Alesina et al. (2003) also find strong correlations between ethno-linguistic fractionalization and geographical variables. This allows us to isolate the effect of fractionalization on investment and to conduct a Hansen over-identification test for exogeneity of the instruments.

Regressions 9b and 9c of Table 3 report the first and second stage of this IV regression and confirm the detrimental effect of volatility on growth. Although the positive effect of investment shares on growth are now bigger, the qualitative results are similar to the ML estimates presented in regression 9a. ${ }^{13}$ The first stage confirms that ethno-linguistic fractionalization has a strong effect on the investment share. The F-test on the excluded instruments is unfortunately below 9.08 (5\% critical value for 3 instruments) which means that the relative bias of using these instruments is slightly larger than $10 \%$ of the inconsistency of regression 9a. Our estimate of investment on growth is therefore still biased downwards (Stock and Yogo, 2002). However, if we repeat the IV regressions with only ethnic fractionalization we

\footnotetext{
11 They base their data on the World Christian Encyclopedia. They argue that fractionalization is a poor predictor of civil war compared to ethnic polarization. We are therefore more confident that there is no effect of fractionalization on growth via the link of conflicts.

${ }^{12}$ Montalvo and Reynal-Querol (2005b) argue that ethnic polarization affects investment but not growth, while fractionalization affects growth directly as in Easterly and Levine (1997), but not investment. However, these growth regressions do not control for population growth or volatility. If we run regression 9a with ethnic fractionalization and polarization using their ethnicity data, we find no growth effects of these two variables. Adding polarization to the first stage yields no effect of polarization, but still gives a significant negative effect of fractionalization on investment. Taking the effect of volatility into account seems to have important effects on the link between ethnicity and growth, and should be seen as complementary. Regressions are available on request.

${ }^{13}$ Volatility is not included in the first stage, because strictly speaking this variable is based on the second stage errors. This should not effect our results, since non-instrument exogenous variables are only included for efficiency reasons.
} 
get an F-test value of 11.79. Ethnic fractionalization is therefore a strong predictor of investment, but we note that the true effect of investment on growth should be slightly higher in the reported $2^{\text {nd }}$ stage regressions. On the other hand, using all three instruments allows us to test for their exogeneity. The Hansen test ${ }^{14}$ is passed and implies that our instruments are exogenous. The first stage of the IV regressions shows a large and significant positive correlation with natural resource dependence and the investment share. We cannot claim that this corresponds to a causal effect, but it further explains the positive (although insignificant) direct effect of resource dependence on growth after controlling for volatility. ${ }^{15}$

\subsection{Additional determinants of volatility}

The fact that resource exports are so important to explain volatility leads us to add two domestic and one external effect in Table 4 which may have important explanatory power for a country's output volatility. They also include year dummies in the mean equation to allow for world-wide yearly effects which may influence growth directly, such as growth and recessions of large countries, and for example fuel prices. Regression 10 compares directly to regression 8 of Table 3 and shows no qualitative differences. The first domestic factor is the volatility of the size of government (as a percentage of GDP) from year to year. The revenue, or loss, from sudden changes in resource prices often translates quickly in spending booms or busts in countries with weak institutions. This is essentially a policy variable which can have large effects on growth, the more so if natural resources are an important source of income.

Regression 11 shows indeed a large effect of government spending volatility on output volatility. Controlling for this variable lowers the direct effect of resources on volatility somewhat and significantly increases the log likelihood. Part of spending booms and busts may be explained by competing factions within a country. Ethno-linguistic polarization is a significant predictor of civil war according to Montalvo and Reynal-Querol (2005a). We expect that it therefore also affects output volatility. Regression 12 shows that it is indeed significant and also lowers the effects of both resource dependence and government spending volatility. This indicates that

\footnotetext{
${ }^{14}$ Robust to heteroskedasticity and autocorrelation.

15 A complicating factor is that the predicted investment share in regression 9c is a generated regressor (Pagan, 1984), which causes standard errors to be too small (although coefficients are consistently estimated). A common solution is to block bootstrap the standard errors, which re-samples every replication from within each cluster (each country) to allow errors to be correlated within countries, but independent between countries. Since it is very difficult to achieve convergence of the log likelihood function for every replication, we use the fact that block bootstrapping is asymptotically equivalent to panel robust sandwich standard errors (Cameron and Trivedi, 2005). The latter correction of the standard errors is what we use in all regressions, including 9c, to allow for within-country correlation of the errors. We can therefore directly interpret the results.
} 
natural resource dependence in itself is not necessarily bad. It is rather how a country deals with the proceeds, and whether it is able to smooth the resource revenues, that determine the effect on volatility.

The external factor highlighted in regression 13 is the fluctuation in changes of the terms of trade (exports over imports). This captures the resource effects as they influence the value of

Table 4: Additional Determinants of Volatility and the Role of Financial Development

\begin{tabular}{|c|c|c|c|c|c|c|}
\hline \multirow{2}{*}{$\begin{array}{c}\text { Dependent Variable } \\
\text { (constant } 2000 \text { international dollars, PWT } \\
6.2 \text { ) }\end{array}$} & \multicolumn{3}{|c|}{ yearly GDP growth per capita $1970-2003$} & \multirow[b]{2}{*}{13} & \multirow[b]{2}{*}{$10^{\prime}$} & \multirow[b]{2}{*}{$13^{\prime}$} \\
\hline & $\begin{array}{c}10 \\
\text { Core } \\
\text { regression }\end{array}$ & 11 & 12 & & & \\
\hline \multicolumn{7}{|l|}{ Mean equation } \\
\hline Average investment share of GDP & $\begin{array}{l}0.044^{*} \\
(0.025)\end{array}$ & $\begin{array}{c}0.048 * \\
(0.026)\end{array}$ & $\begin{array}{c}0.049 * \\
(0.027)\end{array}$ & $\begin{array}{c}0.064 * * \\
(0.027)\end{array}$ & $\begin{array}{l}0.048 * \\
(0.026)\end{array}$ & $\begin{array}{c}0.064 * * \\
(0.027)\end{array}$ \\
\hline 1st lag GDP per capita growth & $\begin{array}{c}0.224 * * * \\
(0.027)\end{array}$ & $\begin{array}{c}0.226 * * * \\
(0.028)\end{array}$ & $\begin{array}{c}0.223^{* * *} \\
(0.029)\end{array}$ & $\begin{array}{c}0.224 * * * \\
(0.031)\end{array}$ & $\begin{array}{c}0.222 * * * \\
(0.028)\end{array}$ & $\begin{array}{c}0.224 * * * \\
(0.031)\end{array}$ \\
\hline Average population growth rate $1970-2000$ & $\begin{array}{c}-0.490 * * * \\
(0.120)\end{array}$ & $\begin{array}{c}-0.376 * * * \\
(0.128)\end{array}$ & $\begin{array}{c}-0.317 * * \\
(0.138)\end{array}$ & $\begin{array}{c}-0.326^{* *} \\
(0.136)\end{array}$ & $\begin{array}{c}-0.496 * * * \\
(0.123)\end{array}$ & $\begin{array}{c}-0.325^{* *} \\
(0.132)\end{array}$ \\
\hline Initial log per capita GDP & $\begin{array}{c}-0.014^{* * *} \\
(0.002)\end{array}$ & $\begin{array}{c}-0.012^{* * *} \\
(0.002)\end{array}$ & $\begin{array}{c}-0.012 * * * \\
(0.002)\end{array}$ & $\begin{array}{c}-0.010^{* * * *} \\
(0.002)\end{array}$ & $\begin{array}{c}-0.014 * * * \\
(0.003)\end{array}$ & $\begin{array}{c}-0.010 * * * \\
(0.002)\end{array}$ \\
\hline Initial human capital 1970 & $\begin{array}{c}0.002^{* *} \\
(0.001)\end{array}$ & $\begin{array}{c}0.001 \\
(0.001)\end{array}$ & $\begin{array}{l}0.001 * \\
(0.001)\end{array}$ & $\begin{array}{c}0.001 \\
(0.001)\end{array}$ & $\begin{array}{c}0.002^{* *} \\
(0.001)\end{array}$ & $\begin{array}{c}0.001 \\
(0.001)\end{array}$ \\
\hline Volatility $\left(\sigma_{i}\right)$ & $\begin{array}{c}-\mathbf{0 . 8 4 1} * * * \\
(0.266)\end{array}$ & $\begin{array}{c}-\mathbf{0 . 4 7 2} * * * \\
(0.177)\end{array}$ & $\begin{array}{c}-\mathbf{0 . 5 3 7 * * *} \\
(0.195)\end{array}$ & $\begin{array}{c}-\mathbf{0 . 3 2 0} * * \\
(0.129)\end{array}$ & $\begin{array}{c}\mathbf{- 0 . 8 0 7 * *} \\
(0.377)\end{array}$ & $\begin{array}{c}-\mathbf{0 . 3 3 1} * * \\
(0.130)\end{array}$ \\
\hline Initial financial development & $\begin{array}{c}-0.016 * * \\
(0.007)\end{array}$ & $\begin{array}{c}-0.009 \\
(0.005)\end{array}$ & $\begin{array}{l}-0.010^{*} \\
(0.006)\end{array}$ & $\begin{array}{c}-0.006 \\
(0.005)\end{array}$ & $\begin{array}{c}-0.014 * * \\
(0.007)\end{array}$ & $\begin{array}{c}-0.006 \\
(0.005)\end{array}$ \\
\hline Sachs Warner updated openness dummy & $\begin{array}{c}-0.007 \\
(0.004)\end{array}$ & $\begin{array}{c}-0.000 \\
(0.003)\end{array}$ & $\begin{array}{c}-0.001 \\
(0.003)\end{array}$ & $\begin{array}{c}0.001 \\
(0.003)\end{array}$ & $\begin{array}{c}-0.007 \\
(0.005)\end{array}$ & $\begin{array}{c}0.001 \\
(0.003)\end{array}$ \\
\hline Natural resources 1970 & $\begin{array}{c}0.019 \\
(0.015)\end{array}$ & $\begin{array}{c}0.013 \\
(0.013)\end{array}$ & $\begin{array}{c}0.012 \\
(0.014)\end{array}$ & $\begin{array}{c}0.009 \\
(0.014)\end{array}$ & $\begin{array}{c}0.019 \\
(0.018)\end{array}$ & $\begin{array}{c}0.010 \\
(0.014)\end{array}$ \\
\hline Constant & $\begin{array}{c}0.159 * * * \\
(0.026)\end{array}$ & $\begin{array}{c}0.122 * * * \\
(0.022)\end{array}$ & $\begin{array}{c}0.123 * * * \\
(0.021)\end{array}$ & $\begin{array}{c}0.101 * * * \\
(0.017)\end{array}$ & $\begin{array}{c}0.161 * * * \\
(0.030)\end{array}$ & $\begin{array}{c}0.101^{* * * *} \\
(0.017)\end{array}$ \\
\hline \multicolumn{7}{|l|}{ Variance equation } \\
\hline Initial financial development & $\begin{array}{c}-1.615^{* * *} \\
(0.086)\end{array}$ & $\begin{array}{c}-1.227^{* * *} \\
(0.180)\end{array}$ & $\begin{array}{c}-1.234^{* * *} \\
(0.125)\end{array}$ & $\begin{array}{c}-1.039 * * * \\
(0.103)\end{array}$ & $\begin{array}{c}-1.340 * * * \\
(0.277)\end{array}$ & $\begin{array}{c}-0.710 * * * \\
(0.100)\end{array}$ \\
\hline Sachs Warner updated openness dummy & $\begin{array}{c}-0.841^{* * * *} \\
(0.189)\end{array}$ & $\begin{array}{c}-0.921 * * * \\
(0.172)\end{array}$ & $\begin{array}{c}-0.876 * * * \\
(0.162)\end{array}$ & $\begin{array}{c}-0.496 * * * \\
(0.101)\end{array}$ & $\begin{array}{c}-0.843 * * * \\
(0.174)\end{array}$ & $\begin{array}{c}-0.490 * * * \\
(0.128)\end{array}$ \\
\hline Distance to nearest navigable river or coast & $\begin{array}{c}0.001 * * * \\
(0.000)\end{array}$ & $\begin{array}{c}0.001 * * * \\
(0.000)\end{array}$ & $\begin{array}{c}0.001^{* * *} \\
(0.000)\end{array}$ & $\begin{array}{c}0.000 * * * \\
(0.000)\end{array}$ & $\begin{array}{c}0.001^{* *} \\
(0.000)\end{array}$ & $\begin{array}{c}0.000 * * \\
(0.000)\end{array}$ \\
\hline Natural resources 1970 & $\begin{array}{c}1.038 * * * \\
(0.352)\end{array}$ & $\begin{array}{c}0.683 * * * \\
(0.219)\end{array}$ & $\begin{array}{c}0.567 * * \\
(0.265)\end{array}$ & $\begin{array}{c}0.123 \\
(0.392)\end{array}$ & $\begin{array}{c}2.741 * * * \\
(0.533)\end{array}$ & $\begin{array}{c}0.125 \\
(0.298)\end{array}$ \\
\hline Government spending volatility 70-03 & & $\begin{array}{c}11.703^{* * *} \\
(1.451)\end{array}$ & $\begin{array}{c}10.226^{* * *} \\
(1.138)\end{array}$ & $\begin{array}{c}9.674 * * * \\
(2.250)\end{array}$ & & $\begin{array}{c}9.729 * * * \\
(2.646)\end{array}$ \\
\hline Ethnolinguistic Polarization index & & & $\begin{array}{c}0.342 * * * \\
(0.096)\end{array}$ & $\begin{array}{c}0.201 * * * \\
(0.050)\end{array}$ & & $\begin{array}{c}0.169 * * * \\
(0.048)\end{array}$ \\
\hline sd ToT index growth 70-03 & & & & $\begin{array}{c}5.963 * * * \\
(0.265)\end{array}$ & & $\begin{array}{c}6.909 * * * \\
(0.452)\end{array}$ \\
\hline Fin. Dev. * Total resources & & & & & $\begin{array}{c}-8.982 * * * \\
(2.863)\end{array}$ & \\
\hline Fin. Dev. * sd ToT growth & & & & & & $\begin{array}{c}-4.399 * * * \\
(1.222)\end{array}$ \\
\hline Constant & $\begin{array}{c}-6.050^{* * *} \\
(0.048)\end{array}$ & $\begin{array}{c}-6.451^{* * *} \\
(0.047)\end{array}$ & $\begin{array}{c}-6.582 * * * \\
(0.026)\end{array}$ & $\begin{array}{c}-7.356 * * * \\
(0.026)\end{array}$ & $\begin{array}{c}-6.082^{* * *} \\
(0.045)\end{array}$ & $\begin{array}{c}-7.420 * * * \\
(0.022)\end{array}$ \\
\hline Year dummies in mean equation & yes & yes & yes & yes & yes & yes \\
\hline Observations & 2024 & 2024 & 2024 & 2024 & 2024 & 2024 \\
\hline Countries & 62 & 62 & 62 & 62 & 62 & 62 \\
\hline Log Likelihood & 3723.5 & 3751.0 & 3753.9 & 3793.7 & 3727.9 & 3794.3 \\
\hline
\end{tabular}

Clustered (by country) standard errors in parentheses $* * * \mathrm{p}<0.01, * * \mathrm{p}<0.05,{ }^{*} \mathrm{p}<0.1$. 
exports, and of imports through appreciation of the exchange rate. It is highly significant and lowers the direct effect of resource dependence on output volatility. Terms of trade and government spending shocks seem to be most important.

\subsection{Can financial development mitigate the causes of volatility?}

Table 4 also looks at the nonlinear effects that initial financial development may have on long-run output volatility. So far, we always found significant negative effects of financial development on output volatility. Regressions $10^{\prime}$ and $13^{\prime}$ correspond to 10 and 13 , but each adds an interaction

Table 5: Interacting Volatility with Initial Financial Development in Mean Equation

\begin{tabular}{|c|c|c|c|}
\hline & \multicolumn{3}{|c|}{ yearly GDP growth per capita 1970-2003 } \\
\hline & 14 OLS & $15 \mathrm{ML}$ & $16 \mathrm{ML}$ \\
\hline \multicolumn{4}{|l|}{ Mean equation } \\
\hline Average investment share of GDP 70-03 & $\begin{array}{c}0.056^{* *} \\
(0.027)\end{array}$ & $\begin{array}{c}0.043 * * \\
(0.021)\end{array}$ & $\begin{array}{c}0.044 * * \\
(0.021)\end{array}$ \\
\hline 1st lag GDP per capita growth & $\begin{array}{c}0.168^{* * * *} \\
(0.033)\end{array}$ & $\begin{array}{c}0.219 * * * \\
(0.028)\end{array}$ & $\begin{array}{c}0.219 * * * \\
(0.028)\end{array}$ \\
\hline Average population growth rate $70-03$ & $\begin{array}{c}-0.720 * * * \\
(0.174)\end{array}$ & $\begin{array}{c}-0.518 * * * \\
(0.103)\end{array}$ & $\begin{array}{c}-0.542 * * * \\
(0.102)\end{array}$ \\
\hline Initial log per capita GDP & $\begin{array}{c}-0.010 * * * \\
(0.002)\end{array}$ & $\begin{array}{c}-0.015 * * * \\
(0.002)\end{array}$ & $\begin{array}{c}-0.015^{* * *} \\
(0.002)\end{array}$ \\
\hline Initial human capital 1970 & $\begin{array}{c}0.001 \\
(0.001)\end{array}$ & $\begin{array}{c}0.002 * * * \\
(0.001)\end{array}$ & $\begin{array}{c}0.002 * * * \\
(0.001)\end{array}$ \\
\hline Volatility $\left(\sigma_{i}\right)$ & $\begin{array}{c}-\mathbf{- 0 . 5 4 6} * * * \\
(0.095)\end{array}$ & $\begin{array}{c}\mathbf{- 0 . 7 9 9} * * * \\
(0.216)\end{array}$ & $\begin{array}{c}\mathbf{- 0 . 7 2 2} * * * \\
(0.204)\end{array}$ \\
\hline Natural resources 1970 & $\begin{array}{c}-0.006 \\
(0.016)\end{array}$ & $\begin{array}{c}0.014 \\
(0.016)\end{array}$ & $\begin{array}{c}0.014 \\
(0.016)\end{array}$ \\
\hline Initial financial development & $\begin{array}{c}-0.052 * * * \\
(0.013)\end{array}$ & $\begin{array}{c}-0.029 * * * \\
(0.007)\end{array}$ & $\begin{array}{c}-0.031 * * * \\
(0.007)\end{array}$ \\
\hline Sachs Warner updated openness dummy & $\begin{array}{c}0.002 \\
(0.003)\end{array}$ & $\begin{array}{l}-0.003 \\
(0.004)\end{array}$ & $\begin{array}{c}-0.001 \\
(0.004)\end{array}$ \\
\hline Volatility $\left(\sigma_{i}\right) *$ Fin.Dev.1970 & $\begin{array}{c}1.983 * * * \\
(0.519)\end{array}$ & $\begin{array}{c}1.311 * * * \\
(0.441)\end{array}$ & $\begin{array}{c}1.458 * * \\
(0.588)\end{array}$ \\
\hline Constant & $\begin{array}{c}0.111^{* * *} \\
(0.016)\end{array}$ & $\begin{array}{c}0.160 * * * \\
(0.022)\end{array}$ & $\begin{array}{c}0.155^{* * *} \\
(0.022)\end{array}$ \\
\hline \multicolumn{4}{|l|}{ Variance equation } \\
\hline Initial natural resources & & $\begin{array}{c}1.056 * * * \\
(0.366)\end{array}$ & $\begin{array}{c}2.415^{* * *} \\
(0.359)\end{array}$ \\
\hline Initial financial development & & $\begin{array}{c}-1.575^{* * *} \\
(0.169)\end{array}$ & $\begin{array}{c}-1.382 * * * \\
(0.115)\end{array}$ \\
\hline Sachs Warner updated openness dummy & & $\begin{array}{c}-0.846 * * * \\
(0.233)\end{array}$ & $\begin{array}{c}-0.841 * * * \\
(0.173)\end{array}$ \\
\hline Distance to nearest navigable river or coast & & $\begin{array}{c}0.001 * * * \\
(0.000)\end{array}$ & $\begin{array}{c}0.001^{* * * *} \\
(0.000)\end{array}$ \\
\hline Fin. Dev. * Total resources & & & $\begin{array}{c}-\mathbf{7 . 0 6 7} * * * \\
(1.590)\end{array}$ \\
\hline Constant & & $\begin{array}{c}-6.076 * * * \\
(0.076)\end{array}$ & $\begin{array}{c}-6.101 * * * \\
(0.051)\end{array}$ \\
\hline Year dummies in mean equation & yes & yes & yes \\
\hline Observations & 2024 & 2024 & 2024 \\
\hline Clusters & 62 & 62 & 62 \\
\hline Log Likelihood & 3389.8 & 3728 & 3731.4 \\
\hline
\end{tabular}

Standard errors are clustered by country. ${ }^{* * *} \mathrm{p}<0.01,{ }^{* *} \mathrm{p}<0.05,{ }^{*} \mathrm{p}<0.10$. 
term with financial development in the volatility regression. Clearly, those countries that were more financially developed in 1970 suffered much less from the effects that resource dependence and terms of trade shocks have on volatility. They are expected to have grown faster as a result.

Well developed financial system can thus alleviate some of the harmful consequences of natural resource dependence and terms of trade shocks on macroeconomic volatility and growth.

We develop this point further in Table 5 where we interact volatility with initial financial development in the mean equation. Column 14 repeats the positive interaction between volatility and financial development found in Aghion et al. (2005) and Kose et al. (2006) ${ }^{16}$, where we also measure volatility by the standard deviation of output growth. Their OLS specification however does not allow for simultaneous conditioning of the variance itself. Regression 15 does and allows for an interaction of financial development with the predicted standard deviation of unanticipated growth shocks from regression $10 .{ }^{17}$ The result is a significant positive coefficient while all other conditioning variables still explain variance and output growth rather well. Regression 16 is a similar expansion of regression $10^{\prime}$ of Table 4. Not only does financial development alleviate the strong effect of resources on volatility, it also cushions a country against harmful volatility itself. Increasing financial development from $20 \%$ to $30 \%$ would decrease the effect of volatility on growth to -0.4 , while volatility itself would also be lower by $0.3 \%$-points. This small increase in financial development results in $0.12 \%$-points better yearly growth prospects, ceteris paribus.

\section{Robustness: OECD Sample and Panel Estimates}

Appendix 2 presents a comprehensive robustness exercise for our core regression 10 in section 4 . The main result that volatility is harmful for growth and that volatility increases with resource dependence and decreases with financial development survives if we add the rule of law, incidence of malaria, inflation and size of government, a post-1973-oil-shock dummy or region dummies as additional explanatory variables. The main result also survives if we allow for a link between initial income and output volatility, correlation of growth shocks within countries and correlation across continents and time. We now examine the robustness of our results by empirically assessing the volatility curse for a sample of OECD countries in section 5.1 and then providing panel estimates with country fixed effects in section 2.

\footnotetext{
${ }^{16}$ Kose et al. focus on financial integration measured as equity market liberalization and alternatively the ratio of gross capital flows to GDP which are correlated to the ratio of private credit to GDP.

${ }^{17}$ We use the predicted variance of the errors from the mean equation.
} 


\subsection{Is the detrimental effect of volatility greater in the OECD sample?}

Ramey and Ramey (1995) found evidence that the detrimental effect of volatility on growth was actually slightly larger in OECD countries. This is surprising, because OECD countries have a much higher level of development of institutions and financial markets. Table 6 explores whether our results hold for the much smaller OECD sample. The first column repeats regression ten with the full sample of countries and shows that average volatility within this sample is $4.4 \%$. The second column shows that we also find a somewhat stronger effect of volatility on growth in OECD countries. This does not mean, however, that volatility is a bigger problem in these

Table 6: Does the OECD Suffer from a Volatility Curse?

\begin{tabular}{|c|c|c|c|}
\hline \multirow{2}{*}{$\begin{array}{c}\text { Dependent Variable } \\
\text { (constant } 2000 \text { international dollars, PWT } \\
6.2 \text { ) }\end{array}$} & \multicolumn{3}{|c|}{ "yearly GDP growth per capita 1970-2003 } \\
\hline & $\begin{array}{c}10 \\
\text { Full Sample }\end{array}$ & 10 OECD & 13 OECD \\
\hline \multicolumn{4}{|l|}{ Mean equation } \\
\hline Average investment share of GDP & $\begin{array}{l}0.044^{*} \\
(0.025)\end{array}$ & $\begin{array}{l}-0.015 \\
(0.016)\end{array}$ & $\begin{array}{l}-0.013 \\
(0.015)\end{array}$ \\
\hline 1st lag GDP per capita growth & $\begin{array}{c}0.224 * * * \\
(0.027)\end{array}$ & $\begin{array}{c}0.284^{* * *} \\
(0.045)\end{array}$ & $\begin{array}{c}0.263^{* * *} \\
(0.047)\end{array}$ \\
\hline Average population growth rate $1970-2000$ & $\begin{array}{c}-0.490^{* * * *} \\
(0.120)\end{array}$ & $\begin{array}{c}-0.361^{* *} \\
(0.161)\end{array}$ & $\begin{array}{c}-0.323^{* *} \\
(0.141)\end{array}$ \\
\hline Initial log per capita GDP & $\begin{array}{l}-0.014 * * * \\
(0.002)\end{array}$ & $\begin{array}{c}-0.024 * * * \\
(0.002)\end{array}$ & $\begin{array}{c}-0.021 * * * \\
(0.003)\end{array}$ \\
\hline Initial human capital 1970 & $\begin{array}{c}0.002 * * \\
(0.001)\end{array}$ & $\begin{array}{c}0.002 * * * \\
(0.000)\end{array}$ & $\begin{array}{c}0.002 * * * \\
(0.000)\end{array}$ \\
\hline Volatility $\left(\sigma_{i}\right)$ & $\begin{array}{c}\mathbf{- 0 . 8 4 1 * * *} \\
(0.266)\end{array}$ & $\begin{array}{c}-1.086 * * \\
(0.504)\end{array}$ & $\begin{array}{c}\mathbf{0 . 2 3 5} \\
(0.256)\end{array}$ \\
\hline Initial financial development & $\begin{array}{c}-0.016 * * \\
(0.007)\end{array}$ & $\begin{array}{l}-0.006 \\
(0.007)\end{array}$ & $\begin{array}{c}0.008 * * * \\
(0.003)\end{array}$ \\
\hline Sachs Warner updated openness dummy & $\begin{array}{l}-0.007 \\
(0.004)\end{array}$ & $\begin{array}{l}-0.000 \\
(0.004)\end{array}$ & $\begin{array}{c}0.010 * * * \\
(0.003)\end{array}$ \\
\hline Natural resources 1970 & $\begin{array}{c}0.019 \\
(0.015)\end{array}$ & $\begin{array}{l}-0.044 \\
(0.044)\end{array}$ & $\begin{array}{c}0.036 * * \\
(0.016)\end{array}$ \\
\hline Constant & $\begin{array}{c}0.159 * * * \\
(0.026)\end{array}$ & $\begin{array}{c}0.265 * * * \\
(0.026)\end{array}$ & $\begin{array}{c}0.191 * * * \\
(0.032)\end{array}$ \\
\hline \multicolumn{4}{|l|}{ Variance equation } \\
\hline Initial financial development & $\begin{array}{c}-1.615^{* * *} \\
(0.086)\end{array}$ & $\begin{array}{c}-1.311^{* * * *} \\
(0.076)\end{array}$ & $\begin{array}{c}-0.713^{* * * *} \\
(0.067)\end{array}$ \\
\hline Sachs Warner updated openness dummy & $\begin{array}{l}-0.841 * * * \\
(0.189)\end{array}$ & $\begin{array}{c}-0.648 * * * \\
(0.068)\end{array}$ & $\begin{array}{c}-0.257 * * * \\
(0.058)\end{array}$ \\
\hline Distance to nearest navigable river or coast & $\begin{array}{c}0.001 * * * \\
(0.000)\end{array}$ & $\begin{array}{c}-0.000 * * * \\
(0.000)\end{array}$ & $\begin{array}{c}0.000 \\
(0.000)\end{array}$ \\
\hline Natural resources 1970 & $\begin{array}{c}1.038 * * * \\
(0.352)\end{array}$ & $\begin{array}{c}-7.787 * * * \\
(0.776)\end{array}$ & $\begin{array}{c}-4.356 * * * \\
(1.070)\end{array}$ \\
\hline Government spending volatility 70-03 & & & $\begin{array}{c}20.044 * * * \\
(4.775)\end{array}$ \\
\hline Ethnolinguistic Polarization index & & & $\begin{array}{c}-0.762 * * * \\
(0.105)\end{array}$ \\
\hline sd ToT index growth 70-03 & & & $\begin{array}{c}8.037 * * * \\
(0.543)\end{array}$ \\
\hline Constant & $\begin{array}{l}-6.050 * * * \\
(0.048)\end{array}$ & $\begin{array}{c}-6.112 * * * \\
(0.048)\end{array}$ & $\begin{array}{c}-7.700 * * * \\
(0.038)\end{array}$ \\
\hline $\begin{array}{c}\text { Volatility within sample } \\
\text { (s.d.) }\end{array}$ & $\begin{array}{c}0.044 \\
(0.016)\end{array}$ & $\begin{array}{l}0.021 \\
(0.006)\end{array}$ & \\
\hline Year dummies in mean equation & yes & yes & yes \\
\hline Observations & 2024 & 782 & 759 \\
\hline Countries & 62 & 23 & 23 \\
\hline Log Likelihood & 3723.5 & 1947.2 & 1914.4 \\
\hline
\end{tabular}


developed countries. The standard error has also increased by enough to make both results indistinguishable from each other, and the predicted sample volatility for OECD countries is at least half that of the full sample. The net effect on growth is thus close to half what it is for the full set of countries, and much higher for the non-OECD countries.

Regression 13 OECD, corresponding to 13 in the previous table, indicates that the significance of this difference actually disappears when we further condition volatility on government spending volatility, ethnic tensions, and volatility of the terms of trade. In fact, for the developed OECD countries there appear to be no negative effect of output volatility. They are sufficiently open to international trade and financially developed to balance the adverse effects of government spending booms and busts and fluctuations in the terms of trade, while these shocks themselves tend to be smaller as well.

An interesting finding is that resource dependence does not increase volatility, but rather decreases it in OECD countries. Countries such as Norway and The Netherlands with significant resource exports have very stable institutions which may be able to turn around any resource curse into a blessing. This is further supported by the positive direct effect of resources on growth in the mean equation of regression 13 of Table 7. Consistent with the result that financial development can alleviate the resource curse, natural resources can be a blessing for countries with the institutional means to spend the proceeds wisely.

\subsection{Short-run panel perspective and fixed-effects estimation}

As is typically done in the literature we have so far focused on the cross-section variation in volatility by assuming constant average volatility over time. Here we allow volatility to be time dependent by building a five-year panel. Instead of using 1970 values of explanatory variables, we use values for 1970, 1975, 1980, and so on, in regressions 17, and non-overlapping five-year means in regressions 19-20, for each year within the respective 5-year period. However, for both the dependent variable and its lag, we still use yearly observations to yield five errors for each five-year period over which to calculate the volatility. For example, the ten growth rates between 1970 and 1980 are regressed on five repeated initial values of 1970 and five initial values of 1975 , or regressed on five repeated means calculated over the years 1970-75, and five means calculated over the years 1975-1980. In both cases $\sigma_{i t}$ is the standard deviation over the errors of period $t$ to $t+5$. This is a short time period for a standard deviation, but on the other hand it allows institutions and other determinants of growth and volatility to change over time. We estimate the following panel data specification: 


$$
\begin{gathered}
\Delta \log \left(y_{i t}\right)=\lambda \sigma_{i t}+\mathbf{X}_{i t} \boldsymbol{\theta}+\mathbf{Z}_{i t} \boldsymbol{\beta}+d_{t}+\varepsilon_{i t}, \quad \sigma_{i t}^{2}=\exp \left(\mathbf{Z}_{i t} \boldsymbol{\gamma}+c_{t}\right) \quad \text { and } \\
\varepsilon_{i t} \square N\left(0, \sigma_{i t}^{2}\right), \quad i=1, . ., N, \quad t=1, . ., T .
\end{gathered}
$$

$\mathbf{Z}_{\text {it }}$ now includes time-varying data on financial development, resource dependence, and so on, which also allows volatility to vary over time. As various countries become more open to the world economy over the years they may as a consequence become less volatile. This allows for a richer story than the hypothesis tested so far, namely that countries which were open in 1970 were less volatile in the 33 years thereafter. Furthermore, we can factor out the effect of unobserved fixed effects on growth. To do this, we apply the within-transformation (subtracting the mean of each variable over the period 1970-2003 per country from itself) on all variables and re-estimate the panel with maximum likelihood. The coefficients can then be interpreted as the effect of a change in the variable relative to its country-mean over time. $\sigma_{i t}$ is not de-meaned itself, but represents the volatility of de-meaned growth shocks. One possible drawback is that fixed-effects estimation also factors out important long-run country characteristics for which the parameters are of interest, such as average financial development and natural resource abundance. This is why fixed-effects regressions are not our core specification.

Table 7 reports the panel estimates of the effects of volatility, natural resource dependence, financial development and openness (as well as investment rates, schooling, population growth and initial income per capita) on growth in GDP per capita. We find significant negative effects of volatility on growth in all cases, although short-run volatility over and above long-run volatility (which is absorbed by the fixed effects) is somewhat less significant. We see the most notable differences between the pooled regressions 17a and 18a, and the fixed-effects regressions $17 \mathrm{~b}$ and $18 \mathrm{~b}$ in the variance equation. ${ }^{18}$ Most of the effects from the previous tables are still present in the pooled regressions. After controlling for country fixed effects (e.g., a country's average level of financial development), we see that an increase in financial development does not significantly decrease volatility over a short run period of five years. The strongest remaining effect is that of volatility of changes in the terms of trade. This also affects short-run increases in volatility.

The difference between regressions 18 and 13' of Table 4 and 13 OECD of Table 6 is remarkable. Countries that were financially developed in 1970 could dampen the effect of longrun terms of trade volatility on volatility of unanticipated output growth, but the effect works the

\footnotetext{
${ }^{18}$ The observed fixed effects of distance to the nearest navigable river or coast and long run government spending volatility are factored out by the within transformation. Government spending did not vary enough across 5-year periods to be able to include it in regressions $17 \mathrm{~b}$, and 18b-20. We also left out ethnolinguistic polarization as it limits the sample and would also be absorbed by fixed effects.
} 
Table 7: Panel-ML Estimates of Volatility Curse

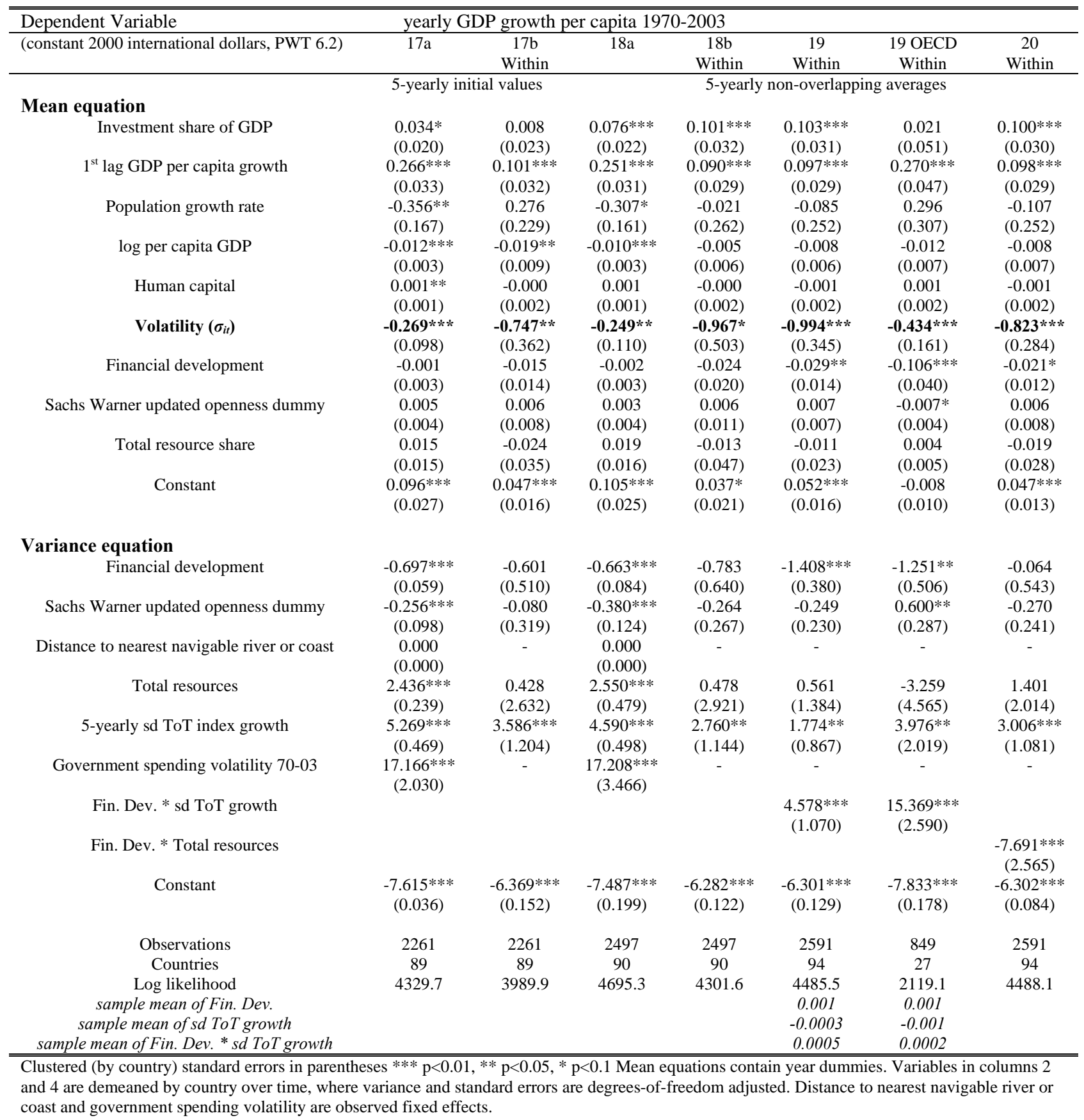

other way around in a short-run, fixed-effects regression both in the full sample and in the OECD sample. Short-run terms of trade volatility may coincide with credit booms, such as during the Asian crisis. In any case, the sample means for these variables (at the bottom of Table 7) are very small which shows that these short-run effects are less important than they appear. The effect of a 
short-run increase in the value of natural resource exports has on the other hand no direct effect on volatility, but still interacts negatively with financial development.

Table 8: Resource Rents and the Volatility Curse

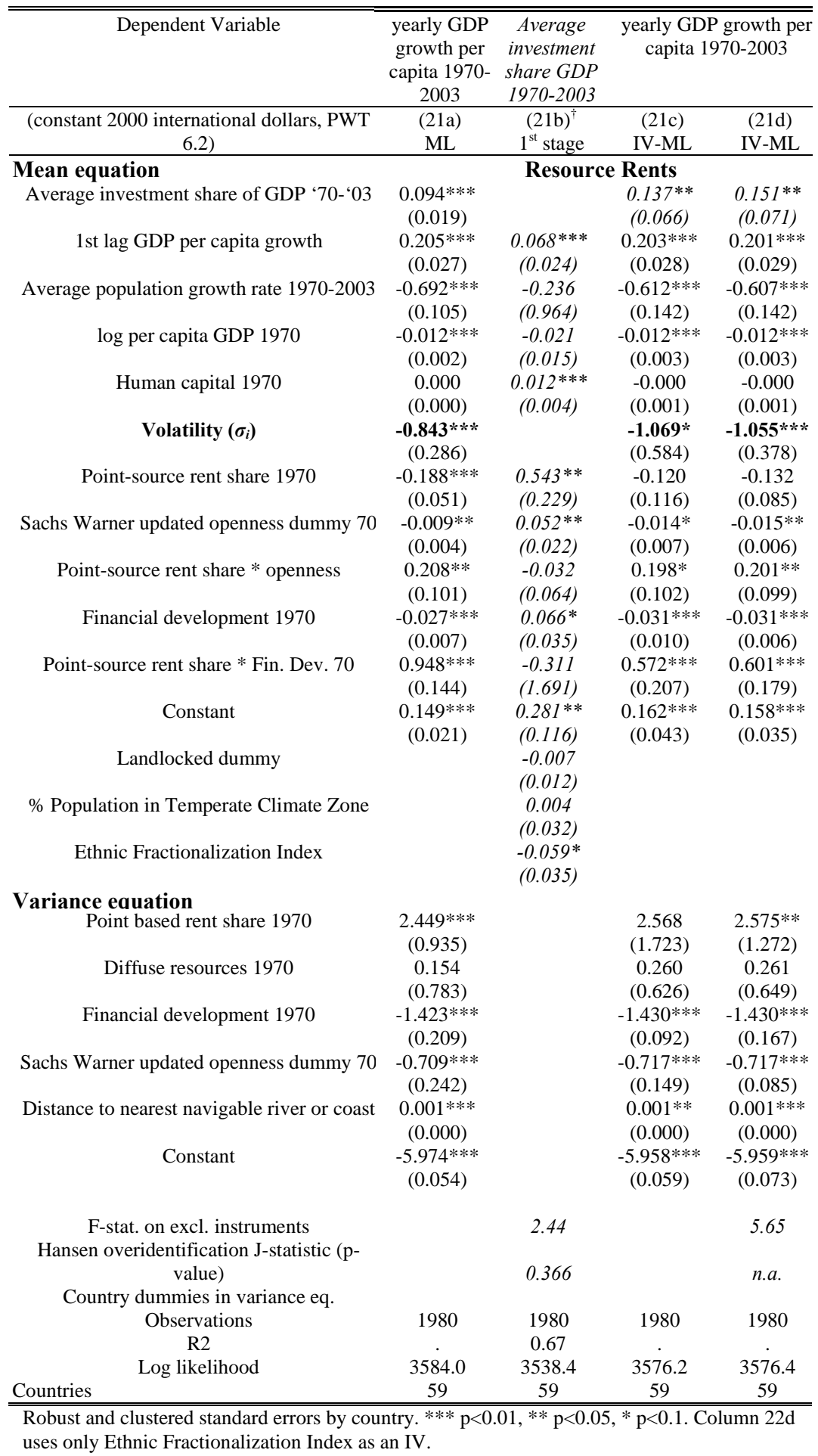




\section{Resource Rents, Volatility and Growth Performance}

The level of rents may be a better measure of resource dependence than export revenue because it takes into account the production costs of resources. However, the resource rents data from the World Bank (2007) are not necessarily superior, since extraction costs are available for much fewer countries than resource revenues and are often proxied by regional/continental rather than actual costs. Rents data have the further drawback that they are available for a smaller sample and only for point-source resources. With this in mind, regression 21a indicates that the GDP share of point-source natural resource rents does exert a negative effect on growth in GDP per capita even after allowing for the effects of volatility on growth. Moreover, 21a shows significant interaction terms of natural resource rents with openness and financial development at the $1 \%$-level. These were insignificant when we used resource revenues in section 4.1. This suggests that the resource curse is less pronounced for countries open to international trade and with well functioning financial systems. For more open countries with a high degree of financial development, the resource curse can even be turned into a blessing. As shown by regressions 21b-d, this finding is robust to instrumenting the investment variable using the same strategy as in section 4.3, with the qualification that our instruments are somewhat weaker in this specification than before, but perform better on the Hansen test.

\section{Conclusion}

We know that countries that are open to international trade, have good institutions and have high levels of education and investment have a better growth performance, while poor countries with high population growth rates find it hard to grow fast. Even if we allow for these traditional determinants of growth, there is still a negative effect of the volatility of unanticipated output growth on long-run growth in income per capita. Allowing for regional dummies, we see that volatility is particularly high in Sub-Saharan Africa, the Middle-East and North Africa and thus their growth performance is worse than in other parts of the world. We probe deeper into the determinants of macroeconomic volatility and provide empirical evidence which suggests that those countries with poor financial systems, restricted international trade, difficult or no access to waterways, and abundant natural resources are more volatile and thus enjoy worse growth prospects. The effect of resources on volatility and thus growth is upheld if we measure dependence by rents (net of extraction costs) rather than export revenue. Similarly, volatility in the terms of trade and the share of government spending appear to increase macroeconomic volatility and worsen growth prospects as well. Some of the harmful effects of terms of trade volatility and resource dependence may be attenuated in countries with well functioning financial 
markets. A corollary of our results is that the quintessential feature of the natural resource curse is the volatility channel. The developed OECD countries suffer much less from volatility and natural resources seem to be beneficial for economic performance. Our panel data estimation results confirm most our cross-country results but suggest, somewhat surprisingly, that well developed financial systems can amplify the effect of short-term terms of trade volatility on volatility on unanticipated output growth. One explanation may be that short-run terms of trade volatility results from credit booms.

\section{References}

Acemoglu, D., and F. Zilibotti, (1997). Was Prometheus Unbound by Chance? Risk, Diversification, and Growth, Journal of Political Economy, 105, 4, 709-751.

Acemoglu, D., S. Johnson, J. Robinson and Y. Thaicharoen (2003). Institutional Causes, Macroeconomic Symptoms: Volatility, Crises and Growth, Journal of Monetary Economics,50,1,49-123.

Aghion, P., G.-M. Angelitos, A. Banerjee and K. Manova (2005). Volatility and Growth: Credit Constraints and Productivity-Enhancing Investment, Working Paper No. 11349, NBER, Cambridge, MA.

Aghion, P., P. Bacchetta, R. Rancière and K. Rogoff (2006). Exchange rate volatility and productivity growth: the role of financial development, Discussion Paper No. 5629, CEPR, London.

Alesina, A., A. Devleeschauwer, W. Easterly, S. Kurlat and R. Wacziarg (2003). Fractionalization, Journal of Economic Growth, 8, 155-194.

Alexeev, M. and R. Conrad (2005). The elusive curse of oil, Working Paper SAN05-07, Terry Sandford Institute of Public Policy, Duke University, Durham.

Barro, R.J. and J.-W. Lee (2000). International data on educational attainment: updates and implications, Working Paper No. 42, Centre for International Development, Harvard University.

Black, F. (1987). Business Cycles and Equilibrium, Basil Blackwell, New York.

Blattman, C., J. Hwang and J.G. Williamson (2007). Winners and losers in the commodity lottery: The impact of terms of trade growth and volatility in the Periphery 1870-1939, Journal of Development Economics, 82, 156-179.

Brunnschweiler, C. and E.H. Bulte (2007). The natural resource curse revised and revisited: A tale of paradoxes and red herrings, Journal of Environmental Economics and Management, to appear. 
Cameron, A.C. and P.K. Trivedi (2005). Microeconometrics: Methods and Applications, Cambridge University Press, New York.

Cashin, P., L. Céspedes and R. Sahay (2002). Keyens, cocoa, and copper: In search of commodity currencies, Working Paper WP/02/223, International Monetary Fund, Washington, D.C..

Deaton, A. (1999). Commodity prices and growth in Africa, Journal of Economic Perspectives, 13, 3, 23-40.

Ding, N. and B.C. Field (2005). Natural resource abundance and economic growth, Land Economics, 81, 3, 496-502.

Easterly, W., M. Kremer, L. Pritchett and L.H. Summers (1993). Good policy or good luck? Country growth performance and temporary shocks, Journal of Monetary Economics, 32, 459-483.

Easterly, W. and R. Levine (1997). Africa's growth tragedy: policies and ethnic divisions, Quarterly Journal of Economics, 12, 1203-1250.

Fatás, A. and I. Mihov (2005). Policy volatility, institutions and economic growth, Discussion Paper No. 5388, CEPR, London.

Gallup, J.L, J.D. Sachs and A. Mellinger (1999). Geography and economic development, Working Paper No. 1, Centre for International Development, Harvard University.

Gylfason, T. (2001). Natural resources, education, and economic development, European Economic Review, 45, 847-859.

Hausman, R. and R. Ribogon (2002). An alternative interpretation of the 'resource curse': theory and policy implications, Working Paper No. 9424, NBER, Cambridge, MA.

Hausman, R., U. Panizza and R. Rigobon (2004). The long-run volatility puzzle of the real exchange rate, Working Paper No. 10751, NBER, Cambridge, MA.

Heston, A., R. Summers and B. Aten (2006). Penn World Table 6.2, Center for International Comparisons of Production, Income and Prices, University of Pennsylvania.

International country risk guide. East Syracuse, NY: Political Risk Services, Institutional Reform and Informational Sector, 2006 and earlier years.

International Monetary Fund (2006, and earlier). Annual Report on Exchange Arrangements and Restrictions, International Monetary Fund, Washington, D.C.

Karl, T.L. (1997). The Paradox of Plenty: Oil Booms and Petro-states, University of California Press, Berkeley.

Koren, M. and S. Tenreyro (2007). Volatility and Development, Quarterly Journal of Economics, 122, 1, 243-287. 
Kose, M.A., E.S. Prasad and M.E. Terrones, (2006). How do trade and financial integration affect the relationship between growth and volatility?, Journal of International Economics, 69, 176-202.

Malik, A. and J. Temple (2006). The geography of output volatility, Journal of Development Economics, forthcoming.

Mansoorian, A. (1991). Resource discoveries and 'excessive' external borrowing, Economic Journal, 101, 1497-1509.

Mirman, L.J. (1971). Uncertainty and optimal consumption decisions, Econometrica, 39, 179185.

Montalvo, J.G. and M. Reynal-Querol (2005a). Ethnic diversity and economic development, Journal of Development Economics, 76, 293-323.

Montalvo, J.G. and M. Reynal-Querol (2005b). Ethnic polarization, potential conflict, and civil wars, American Economic Review, 95, 797-816.

Montalvo, J.G. and M. Reynal-Querol (2007). Fighting against malaria: prevent wars while waiting for the miraculous vaccines, Review of Economics and Statistics, 89, 1, 165-177.

Pagan, A.R. (1984). Econometric Issues in the Analysis of Regressions with Generated Regressors, International Economic Review, 25(1), 221-247.

Pesaran M. H., (2004). General diagnostic tests for cross section dependence in panels, Cambridge Working Papers in Economics No. 435, University of Cambridge.

Ploeg, F. van der and S. Poelhekke (2009). Volatility and the natural resource curse, revised version of CEPR Discussion Paper No. DP6513.

Ramey, G. and V.A. Ramey (1995). Cross-country evidence on the link between volatility and growth, American Economic Review, 85, 5, 1138-1151.

Rose, A.K. and M.M. Spiegel (2007). International financial remoteness and macroeconomic volatility, Journal of Development Economics, forthcoming.

Sachs, J.D. and A.M. Warner (1995 and revised 1997). Natural resource abundance and economic growth, in G. Meier and J. Rauch (eds.), Leading Issues in Economic Development, Oxford University Press, Oxford.

Sala-i-Martin, X., G. Doppelhofer and R.I. Miller (2004). Determinants of Long-Term Growth: A Bayesian Averaging of Classical Estimates (BACE) Approach, American Economic Review, 94, 813-835.

Stock, J.H. and M. Yogo (2002). Testing for weak instruments in linear IV regression, Technical Working Paper 284, NBER, Cambridge, MA. 
UNCTAD (2007). Commodity price statistics, United Nations Conference on Trade and Development, New York, NY.

Wacziarg, R. and K.H. Welch (2008). Trade liberalization and growth: new evidence, World Bank Economic Review, 22, 2, 187-231.

World Bank (2006). World Development Indicators, World Bank, Washington, D.C.

World Bank (2007). Adjusted Net Savings Data, Environmental Economics and Indicators, World Bank, Washington, D.C.

\section{Appendix 1: Data Description}

\begin{tabular}{|c|c|c|}
\hline VARIABLE NAME & DEFINITION & SOURCE \\
\hline GDP/capita growth rate & Ln difference in real GDP per capita, Laspeyres & $\begin{array}{l}\text { PWT } 6.2 \text { from Heston et al } \\
(2006)\end{array}$ \\
\hline Investment share of GDP & Gross fixed capital formation as \% of GDP & $\begin{array}{l}\text { PWT } 6.2 \text { from Heston et al } \\
(2006)\end{array}$ \\
\hline $\begin{array}{l}\text { Average population growth } \\
\text { rate }\end{array}$ & Ln difference in total population & $\begin{array}{l}\text { PWT } 6.2 \text { from Heston et al } \\
(2006)\end{array}$ \\
\hline $\log$ per capita GDP & Ln real GDP per capita & $\begin{array}{l}\text { PWT } 6.2 \text { from Heston et al } \\
(2006)\end{array}$ \\
\hline Human capital & Average schooling years in the population (age 25+) & Barro \& Lee (2000) \\
\hline Natural resources & F.o.b. value of point-source and diffuse resource exports as a percentage of GDP & WDI (2006) \\
\hline Resource rents & $\begin{array}{l}\text { (total sale value - total production costs)/GDP, current US\$ } \\
\text { for bauxite, copper, nickel, tin, zinc, lead, phosphates, iron ore, silver, gold (ores); } \\
\text { brown coal, hard coal, oil, natural gas (fuels) }\end{array}$ & $\begin{array}{l}\text { World Bank (2007) and WDI } \\
(2006)\end{array}$ \\
\hline Financial development & Domestic credit to private sector (\% of GDP) & WDI (2006) \\
\hline $\begin{array}{l}\text { Sachs Warner updated } \\
\text { openness dummy }\end{array}$ & open to trade $=1$ & Wacziarg \& Welch (2008) \\
\hline Point-source resources & $\begin{array}{l}\text { F.o.b. value of exports as a percentage of GDP. Corresponds to SITC section } 3 \\
\text { (mineral fuels) and divisions } 27,28 \text {, and } 68 \text { (nonferrous metals). }\end{array}$ & WDI (2006) \\
\hline Diffuse resources & $\begin{array}{l}\text { F.o.b. value of exports as a percentage of GDP. Corresponds to SITC section: } 2 \\
\text { (crude materials except fuels) excluding divisions 22, } 27 \text { (crude fertilizers and } \\
\text { minerals excluding coal, petroleum, and precious stones), and } 28 \text { (metalliferous } \\
\text { ores and scrap) and sections: } 0 \text { (food and live animals), } 1 \text { (beverages and tobacco), } \\
\text { and } 4 \text { (animal and vegetable oils and fats) and SITC division } 22 \text { (oil seeds, oil nuts, } \\
\text { and oil kernels). }\end{array}$ & WDI (2006) \\
\hline $\begin{array}{l}\text { Distance to nearest } \\
\text { navigable river or coast }\end{array}$ & minimum distance in km, fixed effect & $\begin{array}{l}\text { CID, General Measures of } \\
\text { Geography (2007) }\end{array}$ \\
\hline Landlocked dummy & $=1$ if a country has no access to sea & Gallup et al (1999) \\
\hline $\begin{array}{l}\text { \% population in temperate } \\
\text { climate zone }\end{array}$ & $\% 1995$ pop in Koeppen-Geiger temperate zones (Cf+Cs+Df+DW) & $\begin{array}{l}\text { CID, General Measures of } \\
\text { Geography (2007) }\end{array}$ \\
\hline Ethnic Fractionalization & $\begin{array}{l}\text { Index of ethno-linguistic fractionalization ( } 0 \text { to } 1 \text { ), probability that two randomly } \\
\text { selected individuals from a given country do not belong to same ethnic group. }\end{array}$ & $\begin{array}{l}\text { Montalvo \& Reynal-Querol } \\
(2005)\end{array}$ \\
\hline Ethnic Polarization & $\begin{array}{l}\text { Index of ethno-linguistic polarization (0: many small groups, to 1: two large } \\
\text { groups) }\end{array}$ & $\begin{array}{l}\text { Montalvo \& Reynal-Querol } \\
(2005)\end{array}$ \\
\hline $\begin{array}{l}\text { Government spending } \\
\text { volatility }\end{array}$ & standard deviation of yearly share of government expenditure of GDP & $\begin{array}{l}\text { PWT } 6.2 \text { from Heston et al } \\
(2006)\end{array}$ \\
\hline sd ToT index growth & $\begin{array}{l}\text { standard deviation of yearly terms-of-trade index growth rate, where the terms-of- } \\
\text { trade index is defined as the value of total exports over total imports }\end{array}$ & $\begin{array}{l}\text { PWT } 6.2 \text { from Heston et al } \\
(2006)\end{array}$ \\
\hline Rule of law 1984 & A country's score on the law and order index in 1984 (first year available). & ICRG (2006) \\
\hline Inflation & Yearly CPI inflation, volatility refers to its standard deviation & WDI (2006) \\
\hline Malaria incidence & Yearly incidence of malaria, per capita. & $\begin{array}{l}\text { Montalvo \& Reynal-Querol } \\
(2007)\end{array}$ \\
\hline
\end{tabular}




\section{Appendix 2: Robustness to Alternative Growth Specifications}

The extensive empirical literature on the determinants of economic growth considers several additional variables which may affect output growth. Not accounting for omitted variable bias may cause our results to be spurious. The most robust growth determinants as estimated by Salai-Martin et al. (2004) include schooling, initial GDP per capita and investment, but also malaria prevalence, fraction of GDP in mining and several regional dummies. Table 9 subjects our core growth-volatility specification 10 of Table 4 to a range of competing specifications. We first include each variable one at a time and then combine all in one regression. All regressions show that the effect of volatility and its main sources stand up to this exercise.

Regressions 10a and 10b add the rule of law in 1984 (first available year). Institutional features of countries may affect growth directly, but also affects volatility as emphasized by Acemoglu et al. (2003). They regress the standard deviation of output growth on constraints on the executive and find a robust negative coefficient. Our related institutional variable rule of law captures this effect well in our simultaneous ML setup, but we also show that it hardly affects our main results. We include the average incidence of malaria per capita at the start of our sample in regression 10c to capture additional geographical features (Gallup et al., 1999). Malaria significantly slows growth, but volatility and its sources are not simply capturing the effect of this omitted variable and have robust separate effects on growth. Regression 10d and 10e focus on policy variables. Bad government policy, such as reflected in inflation and possibly an oversized government could hamper growth as well. We include the average yearly inflation rate and the ratio of government expenditure to GDP. They are both insignificant, although inflation volatility does (modestly) increase output volatility.

Regression 10f includes the link between initial income and output volatility as implied by the model of Acemoglu and Zilibotti (1997), while regression 10g includes a post oil-shock (1973) dummy from Ramey and Ramey (1995). Both are significant but they do not change our results much. Remoteness is not significant anymore in 10f, but the effect of volatility is now larger, as is the positive direct effect of resources. The negative indirect effect is still more important. Further robustness of our findings is displayed by regression 10h where region dummies are included in the mean equation. We believe that allowing correlation of growth shocks within countries is important and we have clustered all standard errors. For completeness, regression 10i shows that not doing so yields smaller standard errors. Alternatively, in $10 \mathrm{j}$ we include region dummies again but now we take into account the possibility that unanticipated growth shocks are correlated across continents and time. Still our results hold. Regression 10k puts all additional regressors in one equation. The bottom line is that volatility is harmful to 
growth and that volatility depends negatively on financial development and positively on resource dependence. The latter may have a positive direct effect on growth but it is not robust and in any case nullified by its indirect effect through volatility.

Table 9: Robustness: Alternative Growth Specifications - regressions 10a-10f

\begin{tabular}{|c|c|c|c|c|c|c|}
\hline \multirow{2}{*}{$\begin{array}{c}\text { Dependent Variable } \\
\text { (constant } 2000 \text { int. dollars, PWT 6.2) }\end{array}$} & \multicolumn{5}{|c|}{ yearly GDP growth per capita 1970-2003 } & \multirow[b]{2}{*}{$10 \mathrm{f}$} \\
\hline & $10 \mathrm{a}$ & $10 \mathrm{~b}$ & $10 \mathrm{c}$ & $10 \mathrm{~d}$ & $10 \mathrm{e}$ & \\
\hline \multicolumn{7}{|l|}{ Mean equation } \\
\hline Average investment share of GDP 70-03 & $\begin{array}{l}0.043^{*} \\
(0.025)\end{array}$ & $\begin{array}{l}0.052^{* *} \\
(0.025)\end{array}$ & $\begin{array}{l}0.042^{*} \\
(0.024)\end{array}$ & $\begin{array}{c}0.034 \\
(0.023)\end{array}$ & $\begin{array}{l}0.043^{* *} \\
(0.021)\end{array}$ & $\begin{array}{c}0.009 \\
(0.019)\end{array}$ \\
\hline 1st lag GDP per capita growth & $\begin{array}{c}0.220 * * * \\
(0.027)\end{array}$ & $\begin{array}{c}0.224 * * * \\
(0.030)\end{array}$ & $\begin{array}{c}0.240^{* * *} \\
(0.029)\end{array}$ & $\begin{array}{c}0.216 * * * \\
(0.028)\end{array}$ & $\begin{array}{c}0.221 * * * \\
(0.026)\end{array}$ & $\begin{array}{c}0.223^{* * *} \\
(0.026)\end{array}$ \\
\hline Average population growth rate $70-03$ & $\begin{array}{c}-0.462^{* * *} \\
(0.126)\end{array}$ & $\begin{array}{c}-0.414^{* * *} \\
(0.117)\end{array}$ & $\begin{array}{c}-0.338 * * * \\
(0.122)\end{array}$ & $\begin{array}{c}-0.519 * * * \\
(0.126)\end{array}$ & $\begin{array}{c}-0.414^{* * *} \\
(0.128)\end{array}$ & $\begin{array}{c}-0.616^{* * *} \\
(0.091)\end{array}$ \\
\hline Initial log per capita GDP & $\begin{array}{c}-0.013^{* * *} \\
(0.002)\end{array}$ & $\begin{array}{c}-0.015^{* * *} \\
(0.002)\end{array}$ & $\begin{array}{c}-0.013^{* * *} \\
(0.002)\end{array}$ & $\begin{array}{c}-0.016^{* * *} \\
(0.002)\end{array}$ & $\begin{array}{c}-0.014^{* * *} \\
(0.003)\end{array}$ & $\begin{array}{c}-0.035^{* * *} \\
(0.005)\end{array}$ \\
\hline Initial human capital & $\begin{array}{c}0.002^{* *} \\
(0.001)\end{array}$ & $\begin{array}{c}0.002^{* *} \\
(0.001)\end{array}$ & $\begin{array}{l}0.001^{*} \\
(0.001)\end{array}$ & $\begin{array}{c}0.002^{* * *} \\
(0.001)\end{array}$ & $\begin{array}{c}0.002 * * * \\
(0.001)\end{array}$ & $\begin{array}{c}0.003^{* * *} \\
(0.001)\end{array}$ \\
\hline Volatility $\left(\sigma_{i}\right)$ & $\begin{array}{c}-\mathbf{- 0 . 8 8 3} * * * \\
(0.298)\end{array}$ & $\begin{array}{l}-1.286 * * \\
(0.529)\end{array}$ & $\begin{array}{c}-\mathbf{0 . 5 0 8 * * *} \\
(0.169)\end{array}$ & $\begin{array}{l}\mathbf{- 0 . 6 6 3 * *} \\
(0.280)\end{array}$ & $\begin{array}{c}\mathbf{- 0 . 8 2 5 * *} \\
(0.358)\end{array}$ & $\begin{array}{c}-\mathbf{2 . 1 6 4} * * * \\
(0.579)\end{array}$ \\
\hline Initial financial development & $\begin{array}{c}-0.017 * * \\
(0.007)\end{array}$ & $\begin{array}{c}-0.023^{* *} \\
(0.010)\end{array}$ & $\begin{array}{l}-0.004 \\
(0.004)\end{array}$ & $\begin{array}{c}-0.012 * \\
(0.006)\end{array}$ & $\begin{array}{c}-0.015^{*} \\
(0.009)\end{array}$ & $\begin{array}{c}-0.011^{* *} \\
(0.005)\end{array}$ \\
\hline Sachs Warner updated openness & $\begin{array}{c}-0.007 * \\
(0.004)\end{array}$ & $\begin{array}{c}-0.011 * \\
(0.006)\end{array}$ & $\begin{array}{c}0.001 \\
(0.002)\end{array}$ & $\begin{array}{c}-0.004 \\
(0.004)\end{array}$ & $\begin{array}{c}-0.004 \\
(0.006)\end{array}$ & $\begin{array}{c}-0.020 * * * \\
(0.007)\end{array}$ \\
\hline Natural resources 1970 & $\begin{array}{c}0.020 \\
(0.014)\end{array}$ & $\begin{array}{l}0.037 * \\
(0.020)\end{array}$ & $\begin{array}{c}0.018 \\
(0.015)\end{array}$ & $\begin{array}{c}0.017 \\
(0.016)\end{array}$ & $\begin{array}{c}0.020 \\
(0.030)\end{array}$ & $\begin{array}{c}0.065^{* * *} \\
(0.014)\end{array}$ \\
\hline Constant & $\begin{array}{c}0.155^{* * *} \\
(0.025)\end{array}$ & $\begin{array}{c}0.187 * * * \\
(0.034)\end{array}$ & $\begin{array}{c}0.136 * * * \\
(0.024)\end{array}$ & $\begin{array}{c}0.173 * * * \\
(0.026)\end{array}$ & $\begin{array}{c}0.177 * * * \\
(0.030)\end{array}$ & $\begin{array}{c}0.392 * * * \\
(0.064)\end{array}$ \\
\hline Rule of law 1984 & & $\begin{array}{c}0.001 \\
(0.001)\end{array}$ & & & & \\
\hline Malaria incidence per capita 70-75 & & & & $\begin{array}{c}-0.192^{* * *} \\
(0.034)\end{array}$ & & \\
\hline Average inflation 70-03 & & & & & $\begin{array}{c}-0.000^{*} \\
(0.000)\end{array}$ & \\
\hline Average share of government 70-03 & & & & & $\begin{array}{c}-0.016 \\
(0.012)\end{array}$ & \\
\hline \multicolumn{7}{|l|}{ Variance equation } \\
\hline Initial financial development & $\begin{array}{c}-1.609 * * * \\
(0.101)\end{array}$ & $\begin{array}{c}-1.581^{* * *} \\
(0.057)\end{array}$ & $\begin{array}{c}-0.661 * * * \\
(0.215)\end{array}$ & $\begin{array}{c}-1.589 * * * \\
(0.140)\end{array}$ & $\begin{array}{c}-1.628 * * * \\
(0.280)\end{array}$ & $\begin{array}{c}-0.894 * * * \\
(0.109)\end{array}$ \\
\hline Sachs Warner updated openness & $\begin{array}{c}-0.816^{* * *} \\
(0.183)\end{array}$ & $\begin{array}{c}-0.663^{* * *} \\
(0.158)\end{array}$ & $\begin{array}{c}-0.338 * * \\
(0.172)\end{array}$ & $\begin{array}{c}-0.823^{* * *} \\
(0.209)\end{array}$ & $\begin{array}{c}-0.847^{* * *} \\
(0.326)\end{array}$ & $\begin{array}{c}-0.710^{* * *} \\
(0.157)\end{array}$ \\
\hline Distance to nearest navigable river or coast & $\begin{array}{c}0.001 * * * \\
(0.000)\end{array}$ & $\begin{array}{l}0.000^{* *} \\
(0.000)\end{array}$ & $\begin{array}{l}0.000^{*} \\
(0.000)\end{array}$ & $\begin{array}{c}0.001 * * * \\
(0.000)\end{array}$ & $\begin{array}{l}0.001^{* *} \\
(0.000)\end{array}$ & $\begin{array}{c}0.000 \\
(0.000)\end{array}$ \\
\hline Natural resources 1970 & $\begin{array}{c}1.010^{* * *} \\
(0.230)\end{array}$ & $\begin{array}{c}1.716^{* * * *} \\
(0.366)\end{array}$ & $\begin{array}{c}2.344 * * * \\
(0.454)\end{array}$ & $\begin{array}{c}1.099 * * \\
(0.511)\end{array}$ & $\begin{array}{c}1.044 \\
(1.383)\end{array}$ & $\begin{array}{c}1.320 * * * \\
(0.198)\end{array}$ \\
\hline Average yearly inflation volatility $70-03$ & $\begin{array}{c}0.000 * * * \\
(0.000)\end{array}$ & & & & & \\
\hline Rule of law 1984 & & & $\begin{array}{c}-0.298 * * * \\
(0.020)\end{array}$ & & & \\
\hline Initial log per capita GDP & & & & & & $\begin{array}{c}-0.445^{* * * *} \\
(0.005)\end{array}$ \\
\hline Constant & $\begin{array}{c}-6.067 * * * \\
(0.065)\end{array}$ & $\begin{array}{c}-6.237 * * * \\
(0.072)\end{array}$ & $\begin{array}{l}-5.755^{* * *} \\
(0.073)\end{array}$ & $\begin{array}{c}-6.092 * * * \\
(0.075)\end{array}$ & $\begin{array}{l}-6.042^{* * *} \\
(0.164)\end{array}$ & $\begin{array}{c}-2.505 * * * \\
(0.052)\end{array}$ \\
\hline Observations & 2024 & 1863 & 1863 & 2014 & 2024 & 2024 \\
\hline Clusters & 62 & 57 & 57 & 62 & 62 & 62 \\
\hline Log Likelihood & 3727.3 & 3579.2 & 3634.3 & 3717.6 & 3726.2 & 3768.1 \\
\hline
\end{tabular}

Standard errors clustered by country. ${ }^{* * *} \mathrm{p}<0.01,{ }^{* *} \mathrm{p}<0.05,{ }^{*} \mathrm{p}<0.10$. Region and year dummies are included in the mean equation. 
Table 9: Robustness: Alternative Growth Specifications - regressions 10g-10k

\begin{tabular}{|c|c|c|c|c|c|}
\hline \multirow{2}{*}{$\frac{\text { Mean equation }}{\text { Average investment share of GDP 70-03 }}$} & $10 \mathrm{~g}$ & $10 \mathrm{~h}$ & $10 \mathrm{i}$ & $10 \mathrm{j}$ & $10 \mathrm{k}$ \\
\hline & $\begin{array}{l}0.044^{*} \\
(0.025)\end{array}$ & $\begin{array}{c}0.051^{* * *} \\
(0.018)\end{array}$ & $\begin{array}{l}0.044^{* *} \\
(0.019)\end{array}$ & $\begin{array}{c}0.051^{* * *} \\
(0.017)\end{array}$ & $\begin{array}{c}0.006 \\
(0.018)\end{array}$ \\
\hline 1st lag GDP per capita growth & $\begin{array}{c}0.224 * * * \\
(0.027)\end{array}$ & $\begin{array}{l}0.203^{* * *} \\
(0.029)\end{array}$ & $\begin{array}{c}0.224 * * * \\
(0.017)\end{array}$ & $\begin{array}{c}0.203 * * * \\
(0.053)\end{array}$ & $\begin{array}{c}0.217 * * * \\
(0.032)\end{array}$ \\
\hline Average population growth rate $70-03$ & $\begin{array}{c}-0.490 * * * \\
(0.119)\end{array}$ & $\begin{array}{c}-0.926 * * * \\
(0.149)\end{array}$ & $\begin{array}{c}-0.490 * * * \\
(0.115)\end{array}$ & $\begin{array}{c}-0.926 * * * \\
(0.193)\end{array}$ & $\begin{array}{c}-0.458 * * * \\
(0.124)\end{array}$ \\
\hline Initial log per capita GDP & $\begin{array}{c}-0.014^{* * *} \\
(0.002)\end{array}$ & $\begin{array}{c}-0.014^{* * *} \\
(0.003)\end{array}$ & $\begin{array}{c}-0.014 * * * \\
(0.002)\end{array}$ & $\begin{array}{c}-0.014 * * * \\
(0.002)\end{array}$ & $\begin{array}{c}-0.019 * * * \\
(0.003)\end{array}$ \\
\hline Initial human capital & $\begin{array}{l}0.002^{* *} \\
(0.001)\end{array}$ & $\begin{array}{c}0.000 \\
(0.001)\end{array}$ & $\begin{array}{c}0.002 * * * \\
(0.001)\end{array}$ & $\begin{array}{c}0.000 \\
(0.000)\end{array}$ & $\begin{array}{c}0.002^{* * *} \\
(0.001)\end{array}$ \\
\hline Volatility $\left(\sigma_{i}\right)$ & $\begin{array}{c}-\mathbf{0 . 8 4 2} * * * \\
(0.309)\end{array}$ & $\begin{array}{c}-\mathbf{0 . 6 9 4} * * * \\
(0.246)\end{array}$ & $\begin{array}{c}-\mathbf{0 . 8 4 2} * * * \\
(0.244)\end{array}$ & $\begin{array}{c}-\mathbf{0 . 6 9 4} * * * \\
(0.229)\end{array}$ & $\begin{array}{c}-1.656 * * * \\
(0.491)\end{array}$ \\
\hline Initial financial development & $\begin{array}{c}-0.016^{* *} \\
(0.008)\end{array}$ & $\begin{array}{c}-0.019 * * * \\
(0.006)\end{array}$ & $\begin{array}{c}-0.016^{* * *} \\
(0.005)\end{array}$ & $\begin{array}{c}-0.019 * * \\
(0.009)\end{array}$ & $\begin{array}{l}-0.004 \\
(0.005)\end{array}$ \\
\hline Sachs Warner updated openness & $\begin{array}{l}-0.007 \\
(0.005)\end{array}$ & $\begin{array}{l}-0.006 \\
(0.005)\end{array}$ & $\begin{array}{l}-0.007 \\
(0.005)\end{array}$ & $\begin{array}{l}-0.006 \\
(0.005)\end{array}$ & $\begin{array}{l}-0.000 \\
(0.003)\end{array}$ \\
\hline Natural resources 1970 & $\begin{array}{c}0.019 \\
(0.015)\end{array}$ & $\begin{array}{c}0.024^{* *} \\
(0.010)\end{array}$ & $\begin{array}{c}0.019 \\
(0.013)\end{array}$ & $\begin{array}{c}0.024 * * * \\
(0.004)\end{array}$ & $\begin{array}{c}0.079 * * * \\
(0.028)\end{array}$ \\
\hline Constant & $\begin{array}{c}0.178 * * * \\
(0.028)\end{array}$ & $\begin{array}{c}0.171^{* * * *} \\
(0.023)\end{array}$ & $\begin{array}{c}0.159 * * * \\
(0.026)\end{array}$ & $\begin{array}{c}0.171 * * * \\
(0.014)\end{array}$ & $\begin{array}{c}0.268 * * * \\
(0.039)\end{array}$ \\
\hline Rule of law 1984 & & & & & $\begin{array}{c}-0.006 * * * \\
(0.002)\end{array}$ \\
\hline Malaria incidence per capita 70-75 & & & & & $\begin{array}{c}-0.173^{* * *} \\
(0.038)\end{array}$ \\
\hline Average inflation 70-03 & & & & & $\begin{array}{c}-0.000 \\
(0.000)\end{array}$ \\
\hline Average share of government $70-03$ & & & & & $\begin{array}{l}-0.012 \\
(0.010)\end{array}$ \\
\hline Post-1973 dummy & $\begin{array}{c}-0.020^{* * *} \\
(0.006)\end{array}$ & & & & $\begin{array}{c}-0.017 * * * \\
(0.004)\end{array}$ \\
\hline \multicolumn{6}{|l|}{ Variance equation } \\
\hline Initial financial development & $\begin{array}{c}-1.615^{* * *} \\
(0.141)\end{array}$ & $\begin{array}{c}-1.674^{* * *} \\
(0.050)\end{array}$ & $\begin{array}{c}-1.615^{* * *} \\
(0.115)\end{array}$ & $\begin{array}{c}-1.674 * * * \\
(0.051)\end{array}$ & $\begin{array}{c}-0.588 * * * \\
(0.064)\end{array}$ \\
\hline Sachs Warner updated openness & $\begin{array}{c}-0.841^{* * *} \\
(0.230)\end{array}$ & $\begin{array}{c}-0.812^{* * *} \\
(0.151)\end{array}$ & $\begin{array}{c}-0.841^{* * *} \\
(0.056)\end{array}$ & $\begin{array}{c}-0.812 * * * \\
(0.238)\end{array}$ & $\begin{array}{l}-0.288^{*} \\
(0.149)\end{array}$ \\
\hline Distance to nearest navigable river or coast & $\begin{array}{c}0.001^{* * *} \\
(0.000)\end{array}$ & $\begin{array}{c}0.001 * * * \\
(0.000)\end{array}$ & $\begin{array}{c}0.001 * * * \\
(0.000)\end{array}$ & $\begin{array}{c}0.001^{* * * *} \\
(0.000)\end{array}$ & $\begin{array}{c}0.000 \\
(0.000)\end{array}$ \\
\hline Natural resources 1970 & $\begin{array}{c}1.037 * * * \\
(0.336)\end{array}$ & $\begin{array}{c}1.036 * * * \\
(0.218)\end{array}$ & $\begin{array}{c}1.037 * * * \\
(0.197)\end{array}$ & $\begin{array}{c}1.036^{* * *} \\
(0.194)\end{array}$ & $\begin{array}{c}2.284 * * * \\
(0.497)\end{array}$ \\
\hline Average yearly inflation volatility 70-03 & & & & & $\begin{array}{l}0.000^{*} \\
(0.000)\end{array}$ \\
\hline Rule of law 1984 & & & & & $\begin{array}{c}-0.249 * * * \\
(0.007)\end{array}$ \\
\hline Initial log per capita GDP & & & & & $\begin{array}{c}-0.139 * * * \\
(0.004)\end{array}$ \\
\hline Region dummies in mean equation & no & yes & no & yes & no \\
\hline Clusters (Observations) & 62 (2024) & $62(2024)$ & unclustered (2024) & $8(2024)$ & 57 (2024) \\
\hline Log Likelihood & 3723.5 & 3741.2 & 3723.5 & 3741.2 & 3643.2 \\
\hline
\end{tabular}




\section{CESifo Working Paper Series}

for full list see www.cesifo-group.org/wp

(address: Poschingerstr. 5, 81679 Munich, Germany, office@cesifo.de)

2553 Giorgio Bellettini, Carlotta Berti Ceroni and Giovanni Prarolo, Political Persistence, Connections and Economic Growth, February 2009

2554 Steinar Holden and Fredrik Wulfsberg, Wage Rigidity, Institutions, and Inflation, February 2009

2555 Alexander Haupt and Tim Krieger, The Role of Mobility in Tax and Subsidy Competition, February 2009

2556 Harald Badinger and Peter Egger, Estimation of Higher-Order Spatial Autoregressive Panel Data Error Component Models, February 2009

2557 Christian Keuschnigg, Corporate Taxation and the Welfare State, February 2009

2558 Marcel Gérard, Hubert Jayet and Sonia Paty, Tax Interactions among Belgian Municipalities: Does Language Matter?, February 2009

2559 António Afonso and Christophe Rault, Budgetary and External Imbalances Relationship: A Panel Data Diagnostic, February 2009

2560 Stefan Krasa and Mattias Polborn, Political Competition between Differentiated Candidates, February 2009

2561 Carsten Hefeker, Taxation, Corruption and the Exchange Rate Regime, February 2009

2562 Jiahua Che and Gerald Willmann, The Economics of a Multilateral Investment Agreement, February 2009

2563 Scott Alan Carson, Demographic, Residential, and Socioeconomic Effects on the Distribution of $19^{\text {th }}$ Century US White Statures, February 2009

2564 Philipp Harms, Oliver Lorz and Dieter Urban, Offshoring along the Production Chain, February 2009

2565 Patricia Apps, Ngo Van Long and Ray Rees, Optimal Piecewise Linear Income Taxation, February 2009

2566 John Whalley and Shunming Zhang, On the Arbitrariness of Consumption, February 2009

2567 Marie-Louise Leroux, Endogenous Differential Mortality, Non-Contractible Effort and Non Linear Taxation, March 2009

2568 Joanna Bęza-Bojanowska and Ronald MacDonald, The Behavioural Zloty/Euro Equilibrium Exchange Rate, March 2009 
2569 Bart Cockx and Matteo Picchio, Are Short-Lived Jobs Stepping Stones to Long-Lasting Jobs?, March 2009

2570 David Card, Jochen Kluve and Andrea Weber, Active Labor Market Policy Evaluations: A Meta-analysis, March 2009

2571 Frederick van der Ploeg and Anthony J. Venables, Harnessing Windfall Revenues: Optimal Policies for Resource-Rich Developing Economies, March 2009

2572 Ondřej Schneider, Reforming Pensions in Europe: Economic Fundamentals and Political Factors, March 2009

2573 Jo Thori Lind, Karl Ove Moene and Fredrik Willumsen, Opium for the Masses? Conflict-Induced Narcotics Production in Afghanistan, March 2009

2574 Silvia Marchesi, Laura Sabani and Axel Dreher, Agency and Communication in IMF Conditional Lending: Theory and Empirical Evidence, March 2009

2575 Carlo Altavilla and Matteo Ciccarelli, The Effects of Monetary Policy on Unemployment Dynamics under Model Uncertainty - Evidence from the US and the Euro Area, March 2009

2576 Falko Fecht, Kjell G. Nyborg and Jörg Rocholl, The Price of Liquidity: Bank Characteristics and Market Conditions, March 2009

2577 Giorgio Bellettini and Filippo Taddei, Real Estate Prices and the Importance of Bequest Taxation, March 2009

2578 Annette Bergemann and Regina T. Riphahn, Female Labor Supply and Parental Leave Benefits - The Causal Effect of Paying Higher Transfers for a Shorter Period of Time, March 2009

2579 Thomas Eichner and Rüdiger Pethig, EU-Type Carbon Emissions Trade and the Distributional Impact of Overlapping Emissions Taxes, March 2009

2580 Antonios Antypas, Guglielmo Maria Caporale, Nikolaos Kourogenis and Nikitas Pittis, Selectivity, Market Timing and the Morningstar Star-Rating System, March 2009

2581 António Afonso and Christophe Rault, Bootstrap Panel Granger-Causality between Government Budget and External Deficits for the EU, March 2009

2582 Bernd Süssmuth, Malte Heyne and Wolfgang Maennig, Induced Civic Pride and Integration, March 2009

2583 Martin Peitz and Markus Reisinger, Indirect Taxation in Vertical Oligopoly, March 2009

2584 Petra M. Geraats, Trends in Monetary Policy Transparency, March 2009 
2585 Johannes Abeler, Armin Falk, Lorenz Götte and David Huffman, Reference Points and Effort Provision, March 2009

2586 Wolfram F. Richter, Taxing Education in Ramsey’s Tradition, March 2009

2587 Yin-Wong Cheung, Menzie D. Chinn and Eiji Fujii, China's Current Account and Exchange Rate, March 2009

2588 Alexander Haupt and Silke Uebelmesser, Voting on Labour-Market Integration and Education Policy when Citizens Differ in Mobility and Ability, March 2009

2589 Hans Jarle Kind, Marko Koethenbuerger and Guttorm Schjelderup, Should UtilityReducing Media Advertising be Taxed?, March 2009

2590 Alessandro Cigno, How to Avoid a Pension Crisis: A Question of Intelligent System Design, March 2009

2591 Helmut Lütkepohl and Fang Xu, The Role of the Log Transformation in Forecasting Economic Variables, March 2009

2592 Rainald Borck, Hyun-Ju Koh and Michael Pflüger, Inefficient Lock-in and Subsidy Competition, March 2009

2593 Paolo M. Panteghini, On the Equivalence between Labor and Consumption Taxation, March 2009

2594 Bruno S. Frey, Economists in the PITS?, March 2009

2595 Natalie Chen and Dennis Novy, International Trade Integration: A Disaggregated Approach, March 2009

2596 Frédérique Bec and Christian Gollier, Term Structure and Cyclicity of Value-at-Risk: Consequences for the Solvency Capital Requirement, March 2009

2597 Carsten Eckel, International Trade and Retailing, March 2009

2598 Gianni De Nicolò and Iryna Ivaschenko, Global Liquidity, Risk Premiums and Growth Opportunities, March 2009

2599 Jay Pil Choi and Heiko Gerlach, International Antitrust Enforcement and Multi-Market Contact, March 2009

2600 Massimo Bordignon and Guido Tabellini, Moderating Political Extremism: Single Round vs Runoff Elections under Plurality Rule, April 2009

2601 Ana B. Ania and Andreas Wagener, The Open Method of Coordination (OMC) as an Evolutionary Learning Process, April 2009

2602 Simon Gächter, Daniele Nosenzo, Elke Renner and Martin Sefton, Sequential versus Simultaneous Contributions to Public Goods: Experimental Evidence, April 2009 
2603 Philippe Jehiel and Andrew Lilico, Smoking Today and Stopping Tomorrow: A Limited Foresight Perspective, April 2009

2604 Andreas Knabe, Steffen Rätzel, Ronnie Schöb and Joachim Weimann, Dissatisfied with Life, but Having a Good Day: Time-Use and Well-Being of the Unemployed, April 2009

2605 David Bartolini and Raffaella Santolini, Fiscal Rules and the Opportunistic Behaviour of the Incumbent Politician: Evidence from Italian Municipalities, April 2009

2606 Erkki Koskela and Jan König, Can Profit Sharing Lower Flexible Outsourcing? A Note, April 2009

2607 Michel Beine, Frédéric Docquier and Çağlar Özden, Diasporas, April 2009

2608 Gerd Ronning and Hans Schneeweiss, Panel Regression with Random Noise, April 2009

2609 Adam S. Booij, Bernard M.S. van Praag and Gijs van de Kuilen, A Parametric Analysis of Prospect Theory's Functionals for the General Population, April 2009

2610 Jeffrey R. Brown, Julia Lynn Coronado and Don Fullerton, Is Social Security Part of the Social Safety Net?, April 2009

2611 Ali Bayar and Bram Smeets, Economic, Political and Institutional Determinants of Budget Deficits in the European Union, April 2009

2612 Balázs Égert, The Impact of Monetary and Commodity Fundamentals, Macro News and Central Bank Communication on the Exchange Rate: Evidence from South Africa, April 2009

2613 Michael Melvin, Christian Saborowski, Michael Sager and Mark P. Taylor, Bank of England Interest Rate Announcements and the Foreign Exchange Market, April 2009

2614 Marie-Louise Leroux, Pierre Pestieau and Gregory Ponthiere, Should we Subsidize Longevity?, April 2009

2615 Ronald MacDonald, Lukas Menkhoff and Rafael R. Rebitzky, Exchange Rate Forecasters' Performance: Evidence of Skill?, April 2009

2616 Frederick van der Ploeg and Steven Poelhekke, The Volatility Curse: Revisiting the Paradox of Plenty, April 2009 